Portland State University

PDXScholar

$12-17-1966$

\title{
The Doctrine of the Naqshabandi Order: A Study of Mysticism in Islam
}

Madelain Farah Habib

Portland State University

Follow this and additional works at: https://pdxscholar.library.pdx.edu/open_access_etds

Part of the Religion Commons

Let us know how access to this document benefits you.

\section{Recommended Citation}

Habib, Madelain Farah, "The Doctrine of the Naqshabandi Order: A Study of Mysticism in Islam" (1966). Dissertations and Theses. Paper 59.

https://doi.org/10.15760/etd.59

This Thesis is brought to you for free and open access. It has been accepted for inclusion in Dissertations and Theses by an authorized administrator of PDXScholar. Please contact us if we can make this document more accessible: pdxscholar@pdx.edu. 


\section{Teachine}

Wate thesicis istented

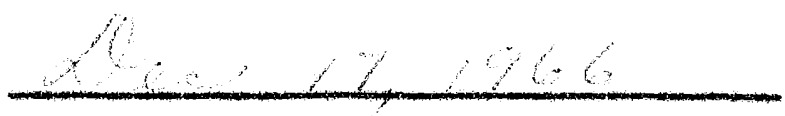

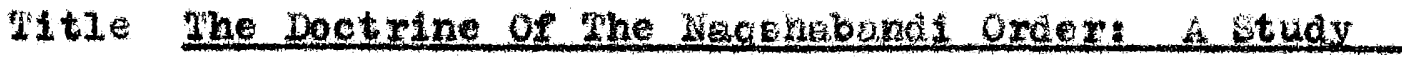
Of ayseticiom In Islam

Abotract approved

\section{(Hajor Profeser)}

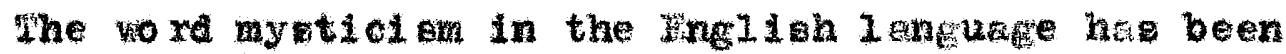
corrupted and abued by ito different useges in the various diseiplines such religion, poetry, ard phi10ophy. In Islam the only word wich refers to a mytic is a sufi. sufian, accoraing to ite adherenta, is the

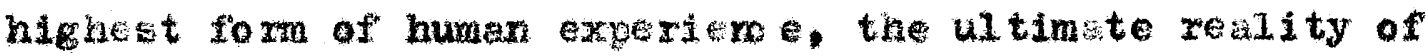
God. The suri theme is "anow thyself and thou wit know Goo."

Buffim ha beer conciadered by sufie and by oxlentaliste whe theient ochool of wem, of guietim, of attaining the highest union and of purification of the coul. It ambodies the etring of various philosophiee and religiono. The tratne are chrietan, wo-platonic, anotio and Indian acetic and religtous philosophy.

The Naghabandi tarica streses the importance and Lnowledge of the preceding shayks, the i character and 
their virtues. howleage of the bileila (chain) which traces ito inception to whammad it a vo very important.

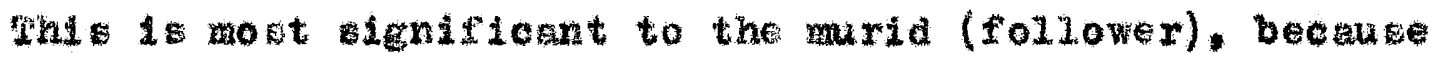
he must cubad to the shaykh and trutc him Implicitiy in order to model his iffe after hin, leading hin to spitual virtue. Not only piritual virtue is trankat ted through the chair but the firt of tace, given by God, to the one who repents and live according to the tartgk. That is to ay, the dilila funetions a compicator between the heart and tite Ileht of God, which is grace. Hevine achleve this tage and with the art of concentration and conteaplation, the true bellever can know God. Ihus the aim of conternlation is opitual union with the one. It is achicved when the raid practices

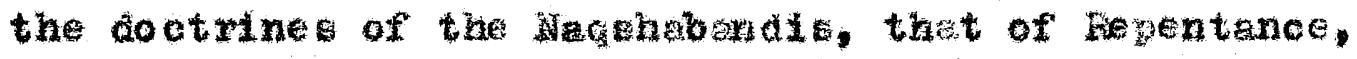
Ihikr and Prayers of the heters. There are preseribed ritual and prectices in thie attainant that mat be ahe red to religiousy. Howerer, this fulfilment is not within reach of every muxid, but the betshebandis olatm that reciting the dhikr (1itany) is the easiegt and simp16 st path to the one. What is diveussed here are thre important inter-related apect of the Nachaband tarifgat coctrine, opiritual virtue (moral and athioal), and an art of concentration.

The quetion now is whare the social implications of sufism? Sufi sm sprans and we nurtured, as in other 


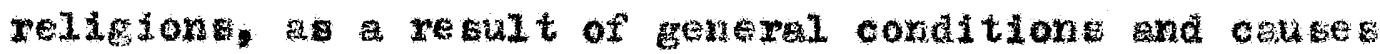
whin the ctrueture of the cocity. Sufism we not only one of the factor that expreased the tpint of socicty in religlour and social tems. 1t wa bleo way of iffe to

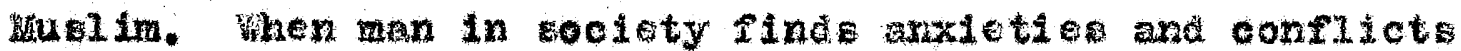

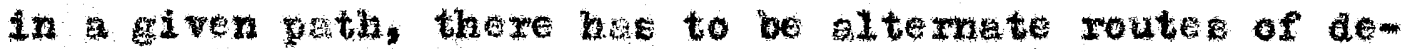
parture, if not, then some conceptualization of thoughts and idea mut tem to fil the vaceum fox hin. If there

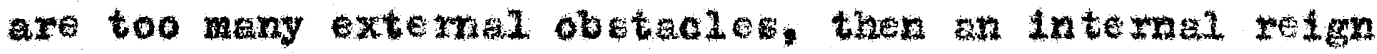
take bold to ive mearine and oxder to man exictence and self fulfilimant. If man canrot find opintual and Intellectual andwer inwardy, he nut find order and mepring in the extema1 world. The balance mat be met in society and tho Wacohaband bufi found it in concentration and conteralation. 
THE DOCTRINE OF THE NAQSHABANDI ORDER:

A STUDY OF MYSTCISM IN ISLAM

by

Madelain Farah Habib

\author{
A THESIS \\ submitted to \\ PORTLAND STATE COLLEGE
}

in partial fulfillment of

the requirements for the degree of

MASTER OF ARTS IN TEACHING

December 1966 
APPROVED:

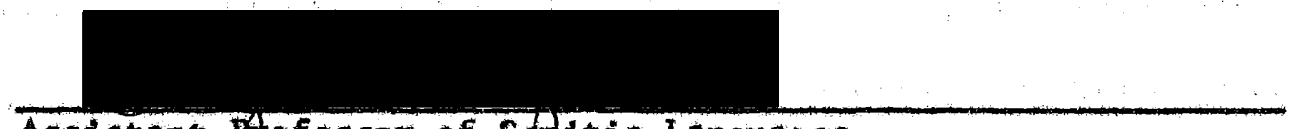

Assistant ofessor of Sexitic Languages
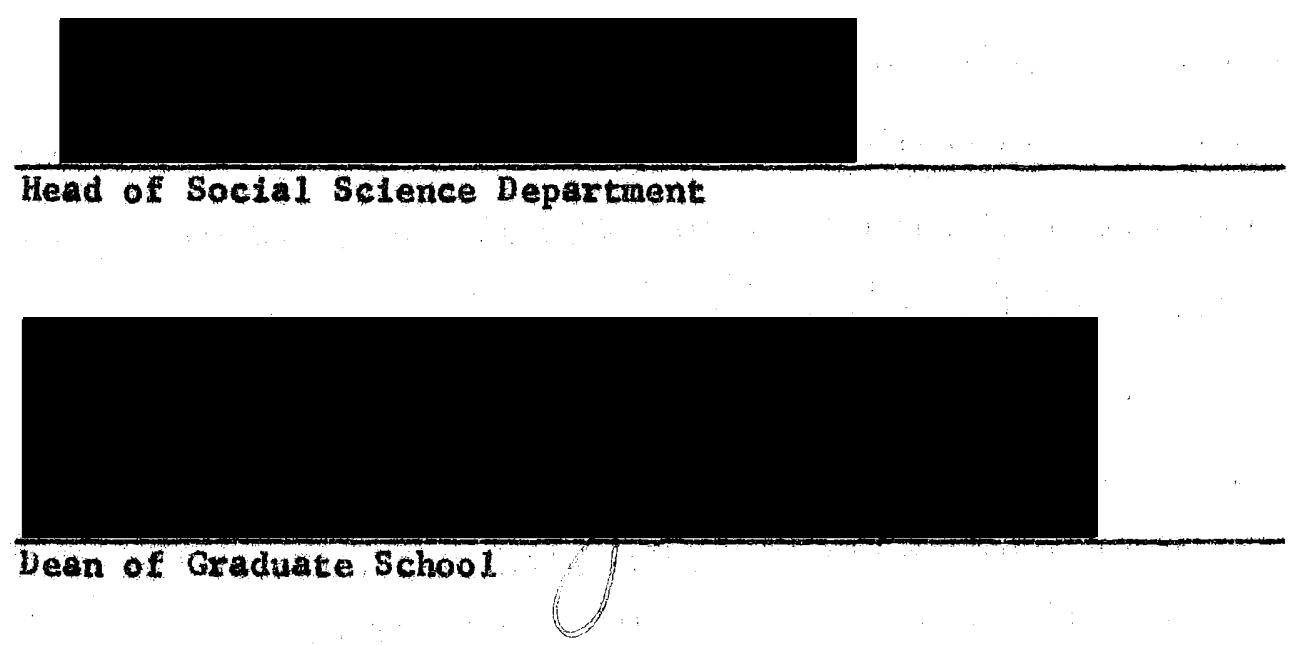

Date thesis is presented

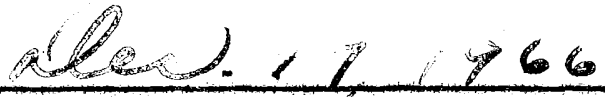

Typed by Madelain Farah Habib 


\section{WRFACE}

The Naghabandi taxiga is examined from the doctrinal as wall as the social point of view. The first chaptex lays the matrix from which to discuss these two aspects of Naqshabandi Sufism. Sufism has wany facets which are touched on only lightly in hopes of stimulatine the general reader to inquire and do research in the areas in which he is nost interested. As to the scholar I ask for his patience for such an attexipt by a neophyte.

Whe sisila is generally the main stream of any given tariga and to the Naqshabardis it is very significant. For thera, the silsila manifests the unseon and seen leaders of the tar Tae which its one doctrinal aspect the knowledge of which is very inportant in their initiation. Because by prayers and contemplation of the shaykhs in the s11a1la, the wurid can invoke the spirituality of the unseen, thus unifying the hearts of the believers. Through the knowledge of the silsila the murid can seek spiritual virtue, which is the thene in essence of the second chapter. Chapter three concentrates on the doctrine of the Naquhabandi tariqa. The embodinenc of this doctrine in a given session to seek mystical union with god is the subject of. Chapter four.

The transliteration system used in the thesis is one adopted by the Encyclopedia of Is lan. The only deviation from this system which I wish to pursue is in the letter "qäf." It is represented here by the letter "q" instead of "g." No atienpt is made to change titles of books or authors' names, they are presented as they appear in the 1iterature. 
ACKNOWLDGEMENTS

As I come around the last corner in my intellectual development at Portland State College, the list of professors and librarians to whom thanks should be extended is very long. I was fortunate to have as my thesis professor and chief advisor, sufi and a poet, Mr. Nazeer ElAzma with whom I spent ruch time and effort in translating and understanding the nuances of difflcult Arabic passages and whose suggestions and advice had been very helpful in this complex undertaking. Sincerest thanks also goes to Mr. Jon Mandaville for serving on the thesis committee and for his criticisms; to Dr. C. Eric Lincoln who served on the comittee and for his assistance, advice and intellectual stimulation. Special indebtedness and thanks to Dr. Frederick Cox who served and assisted on my thesis committee and who with Dx. Victor Dah1 were always attainable during ny undergraduate and graduate work for advice, help as well as recomendations. Last but by no meang least. to my thesis chairman, Dr. Charles White to whom deep gratitude and appreciation is also extended for being my advisor from the first day at Portland state. He patlently ironed out many snags in my undergraduate as well as gradute studies, and who was always behind the scenes in intellectual endeavor.

I would like to take this opportunity to thank Shaykh Sayyid a1-Nuwwerr, a Naqshabandi, of the American University of Cairo without whose asistance, time, and effort, I could not have attained all the pertinent information and matextal needed for this complex subject, and in particular for his contribution in ouclining the present status 
of the Naqshabandi session.

Finally, special thanks goes to mother who bore the sacrifice in alleviating many of my responsibilities to thake this attafraent posstble. There are no vords to express gratitude, I only hope that this offort wil compensate for her deprivation, patience, and understanding. 
He is the Beginning and the Ind,

The Manifest and the Hidden, And the Knower of all things.

Kurdān 


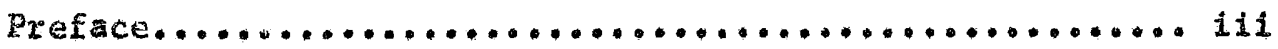

Acknow ledgenents........................... iv

Verse from the kurdan.......................... vi

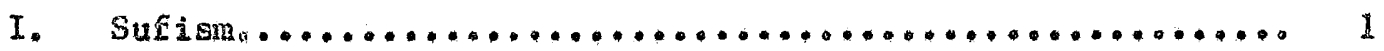

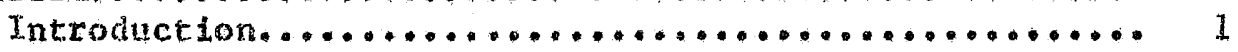

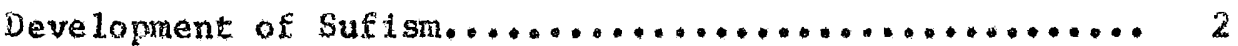

Darly Sufi Doctrine........................... 4

Gutlets ano Characteriscics of Sufista............ 7

II. The S1Lila and Brographical Aspect of the

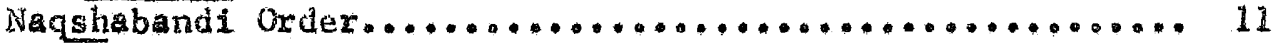

Introduction................................ 11

The silsilas of the order..................... 12

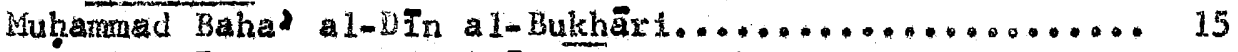

Shaykh Khäid al-Shahrazuri aloNaqushabandi.......... 16

Naqshabandi Shaykhs in Egypt................... 17

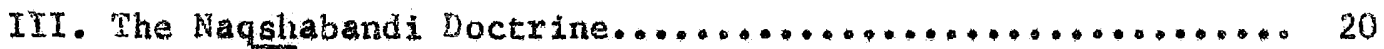

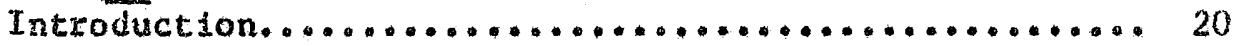

Naqshabandi Initiation........................ 21

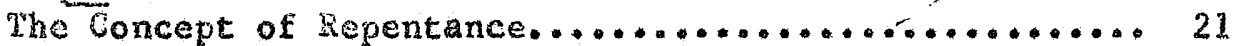

The Concept of bhikr.......................... 22

Sto Basic tomatae of Dhikr..................... 24

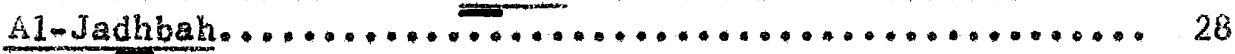

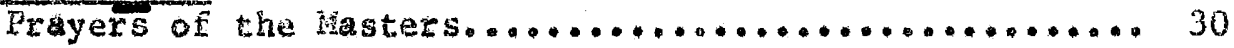

IV. A Naqshabandi Bession.......................... 34

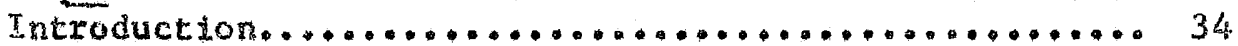

Get Ritual of Conmunication...................... 35

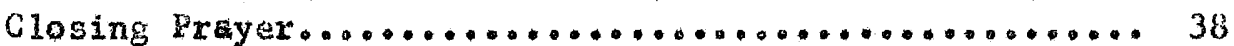

Sumrary and Conclusions........................ 39

Bibliography............................. 44

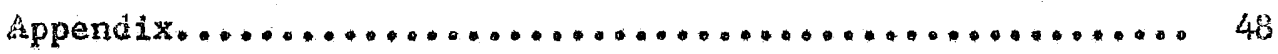


THE DOCTRIHE OF THE NAQSHABANDI ORDER:

A STUDX OF MYSTICISH IN ISLAN

SUPISM

CHATER I

Sufism, although it is translated in English as mysticism, is generally applied to a Mulln rystic, and this is the connotation used here. The Sufists are called Ahl d-Hegg (followers of the Fruth). In the English language the word mysticism has been corrupted and abused by Its different usages in the various disciplines such as religion, poetry, and phllosophy, Sufisw as it stands now in the Muslin world, however, connotes a movement and a discipline with set rituals, doctrines, hierarchy of saints, ${ }^{1}$ and the numerous orders demand loyalty among their adherents. In this context, then, the Sufi orders are considered by thelr members os the institution of the Muslim world, and they represent an impoxtant ecclestastical element in structuring Islamic society, According to its followers, Sufism is the highest form of human experience, the ultimate reality of cod. The oldegt Sufi definition now extant was made by bafuif aldiarkhi (d. 815 A.D.) as "the apprchension of Divine realities and

Isatnthood in Islam is not the same as in Christianity. There is no canonization in Islan, and the word saint is used more out of reverence and custom for the person who hes performed miracles and led religious life. 
renunctation of huraen possesstons." $" 2$

\section{Development of Suflen}

Suften it essence had no exact historlcal inception, but it toole foxa in the eighth and ninth centurles. The adherents stated that it Just existed from the beginning, from the the of Muhamad. Other Suflis asserted that mysticim extated prior to the Kuriñn possibly going beck to the Vedanta. The naw matertals of Sufi principles and dognes are contalned in the Kux'än even though Muhanad laft no systen of dognatic or mytheal theology. The Kuriān for the early sufis is not only the Word of cod but is the primary neans and source of drawing near to Him. The sufta endedvored to produce in thenselves the Frophet's mystical experience "by fervent prayers, by meditating profoundly on the temt 45 whole and in particular on the mysterious passages...concerning the Might-Journey and Ascanston. ${ }^{3}$ Finally, Islam recognizes the busis of religion, In broad terms, as tradition, reasen, and inner 14ght. The meaning of Suflsm for Muslim, is that 1t Is the thnowledge of rellglous things that comes directly, inmediately, to the Individual soul, apart ftom any tradition, apart from any reasoning. $11^{4}$

2Reynold A. Nicholson, A Literary giarory of the Arabs (Cembridge: The University Press, 1953), p. 385 .

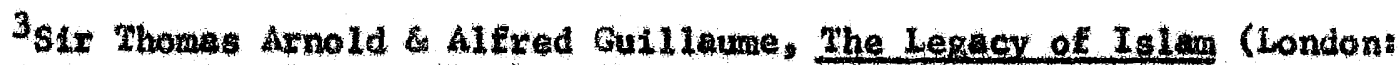
Oxford University Press, 1960). Chapter on Mystcism" tritten by Nicholoon, p. 211. The passages are from the Kur tan.

4Duncan Bleak racDonald, Aspecte of Islam (New York: 1911), po 150. 
Suftin has been constdeted the anclent school of wisdon, of quietza, ${ }^{5}$ of attaining the higheat union and of purification of the soul. Even though it just extsted from the beginning, according to Sufts later 1 thas the orietn of nany orders and eults of a nystical and philosophlcal nature whtch emboded the stratns of varlous philosophtes and religlons. These strains are Christian, Neomplatontc, Gnostic and Indien aseetic and rellglous philosophy. Hovever, the roots of Sufisu, acoording to Inaydit Khan, had been treced to the school which existed in Egypt. Fron this Suft school, he asserted,

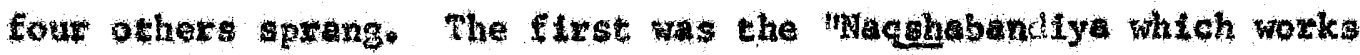
mosty with symbolism, rituel, and ceremony. The second was the pedtriya, which taught wisdon wthin the realn of the asting Islawic relfgion in the East. The thizd was suhrawardiya which taught the aystery of 11fe by the knowledge of metaphysies and the pructice of solf-control. Whe fourth the chishtiya which represented the spiritual idem in the realm of poetry and music. "7 te further agserted that from the above mentioned schools, branches sprang forth in Arabia, Balestine, Turkey, Tartary, Bokhexa, Afghantsten, Indta, Siberia, and othez parts of Asla.

5Nicholson, Litorary, p. 231. Rhan also uses the term "quietiswn" when referring to early developaent of Buftsm.

Wharat Inayat Rhan, The Sut 1 Hesegge of Hamat Inoyat Khan, pub11shed for International Headquarters of the Suft hoverent, Geneva (London: Bartie Kocklift, 19(0), vol. vili, p. 23. There are no foobnotes or bibllography is his eight volumes.

7. Ible, p. 18 . 
Dar 1 Gure Doctrine

It is interesting to note that Islam in the first century of the Hegira ermphesized the fear of God, Hell, death, sin, which was all felt by the sufis. Not unt1 the ninth century was the central thene of Sufl teaching as the Love of God and that this Divine love should be paramount in thete spirttual life. This doctrine, of the "union with God through love," Inspired also $\$ 11$ the religious and ethical concepts in Suftsra.

As far as can be ascertalned, this doctrine ws first propounded by a woman saint and slave, Räbifa al-fAdawiyyah (717-801) of Besza. She deplets the nystic's goal an ecstatic contemplation of the Beloved and it is not definitely ascertained whether the following lines are hers, but they exemplify an early mentfestation of this concept, thet is of Divine love:

I love Thee with two loves, love of my happiness. And pertect love, to love Thee as is Thy due. Ay selfish love is that I do naught But think on thee, excluding all beside But that purest love, which is Thy due, Is that the velis which hide Thee Eall, and I gaze on Thee, No priase to me in either this or that. Hay, Thine the preise for both that love and this.?

After the Introduction of thio new concept, it led, in the extreme forat to pantheism, the recomition of God as the A11. 10

8 Nicola A. Ziadeh, Sanusiya (Leiden: E. J. Brill, 1958), p. 8.

9 Sir Hamilton Gibb, Mohamgedanism (London: Oxford University Rress, 1957), p. 132.

10zladeh, 8. 
There were outer as well as Inward changes in the content of Sufl doctrines. That is, Leadershtp shifted from suardians of the law to men of the ratdie class: mafrifa (expertence) tool the place of Ilm (knowledge) in attaining spixitud purtty, and a bertes of stages

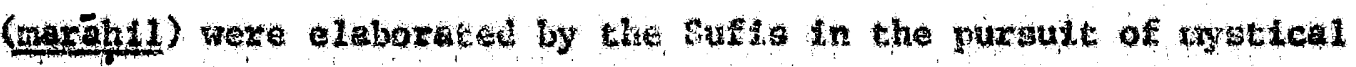
expertence, that is Irepentance, abthence, renunciaton, poverty. patiexce, cruse an Qon setigfaction...(411) purgative atages, which vere latex related to a ladder of ascending degrees of absorption --hutran natuxe, angel te nature, Avine powex. "II

The foundation of this suft theosophy rests on the premise that

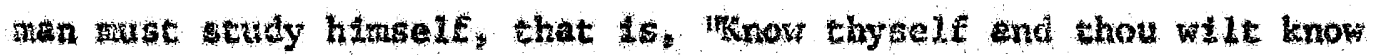

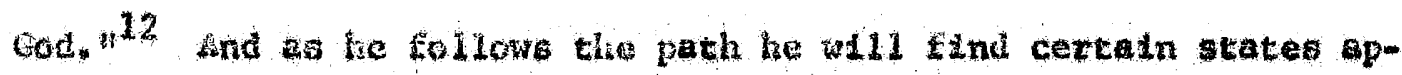
peartrs one aftex anohex, toth vartous degrees of perwenency, unti1 the ond of the rath when ho knows God. whs goal wehough is in the reath of every rember, does not necssmily mean its attaimant.

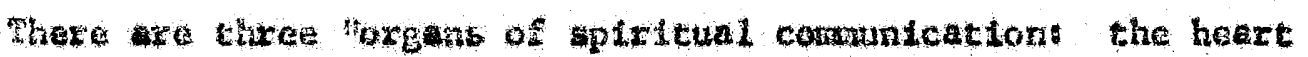

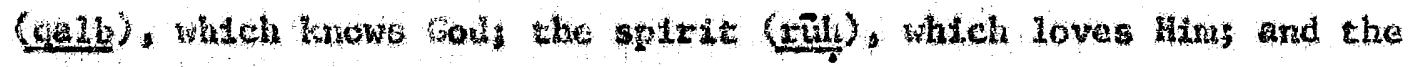

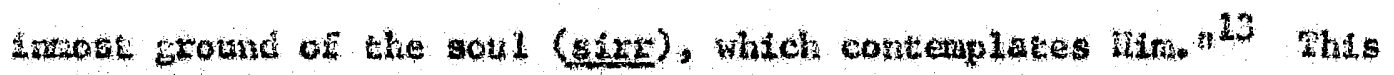

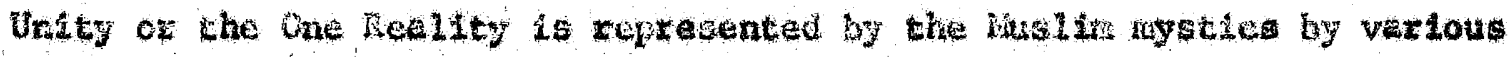

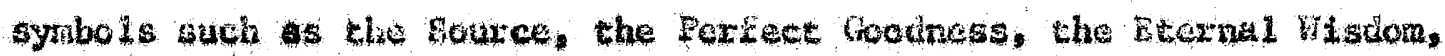

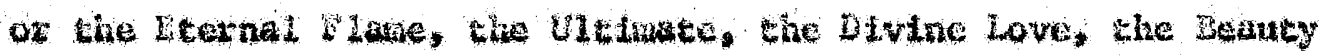
Eupterie and so on the unity is shoped by deep concentation on als unity and oy the reintegration of oneself in Ih

\section{1640.}

12khan, p. 15 .

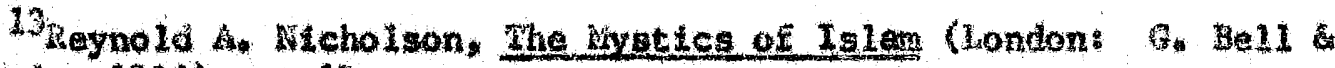
Sone Ltd. 1914$),$ p. 68 . 
Those who labored aligenty long this path to atcin Unity are best exemplitled in the following poen. It represents the opitit of a Sufi's union with God as well as his ecstasy which, as we shell see is attained by a und of autohypnote meduta Sehayd scates that it is he who is blessed to see God thet is able to sung Mus profise and through this inspiration he feels his individunity lost in God:

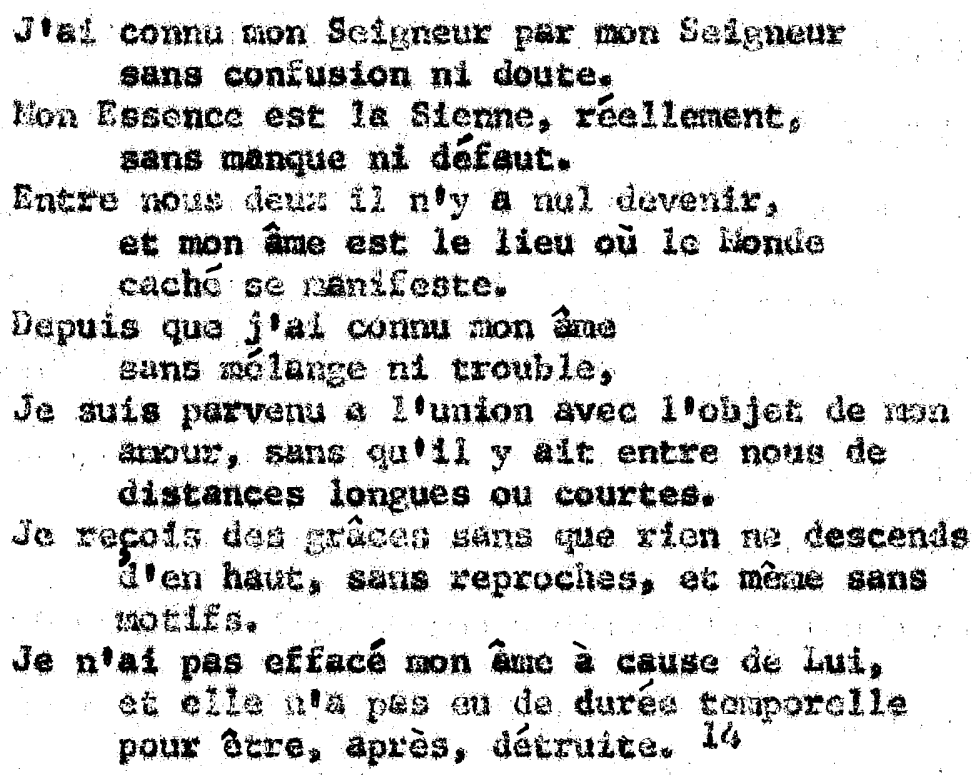

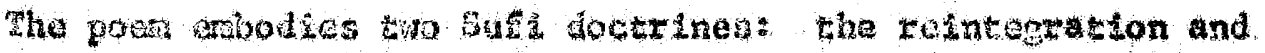

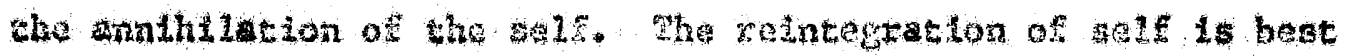

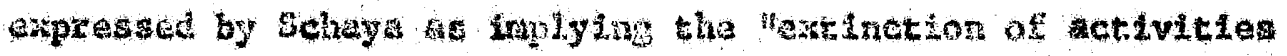

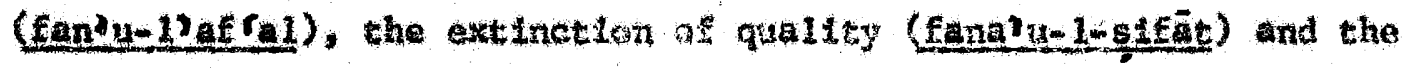

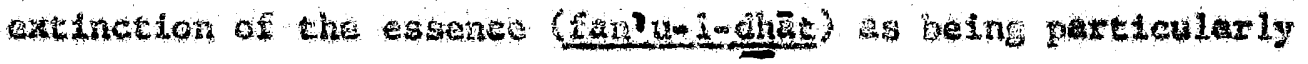

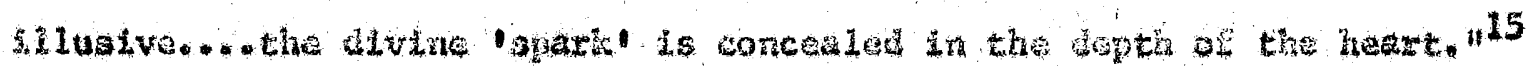

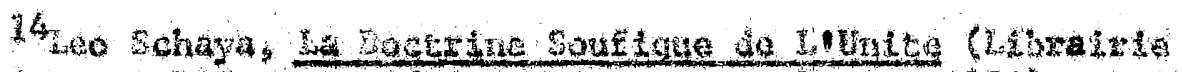

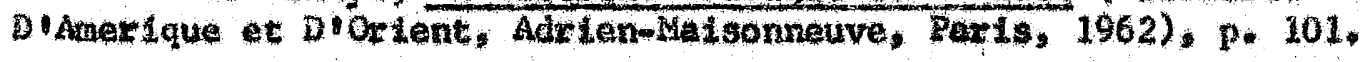

15 Ibla, D. 96. 


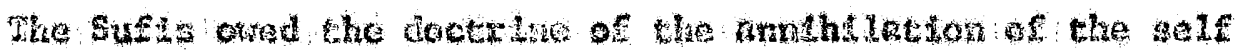

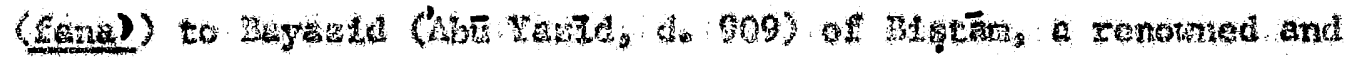

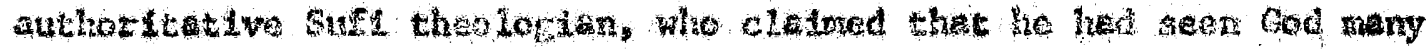

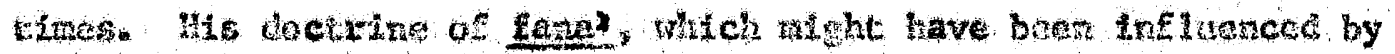

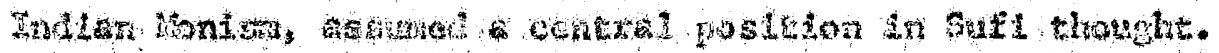

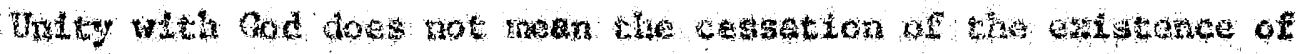

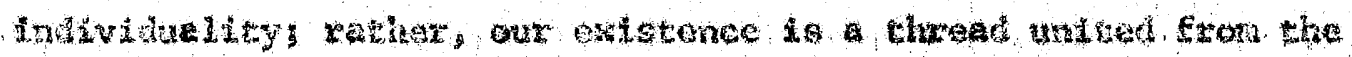

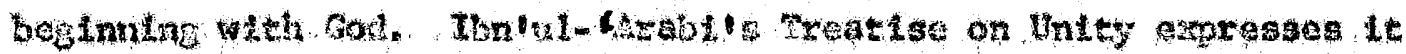
antoly:

Most of those who know bou made a ceasing

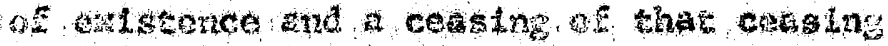
a condleton of actalning tile knowladge of

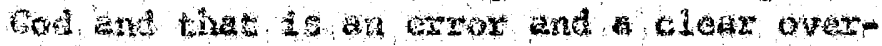
sight. Tor the knowledge of tod does not frearyone the ceastro of whatence, nor the coasing of hese ceolng. For thangs

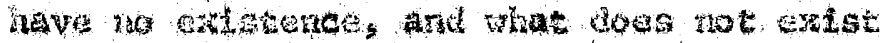
cannot cotse to extst. For the coasing

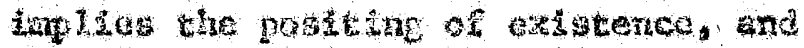

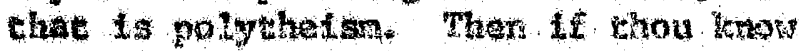

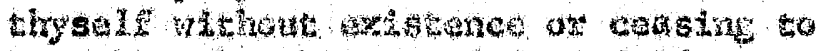

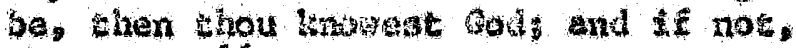
then not. 26

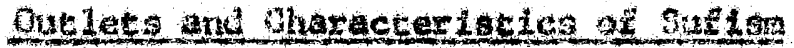

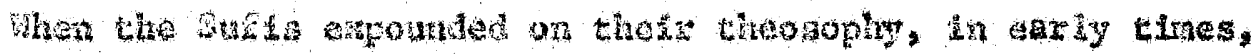

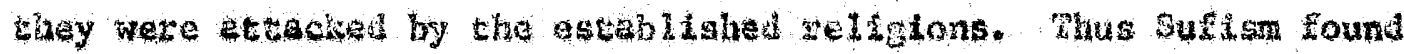

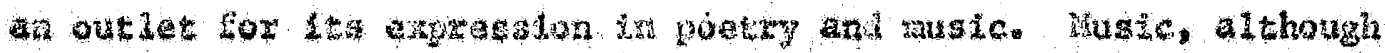

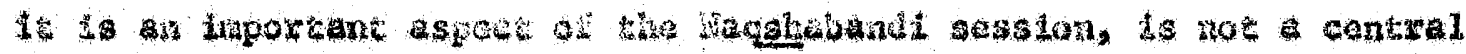

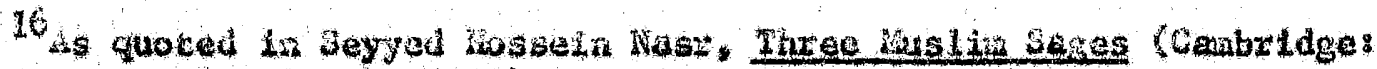
Harvard Indvaratty Erass, 1964), p, 114. 


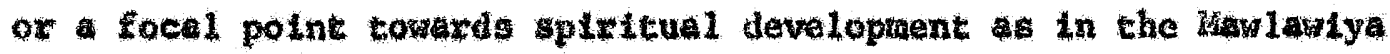
oxcer. For the latter, muate, mantested in dancing, is the nediu by whteh unton wheh cod is attolned. This art of music in suftsm vas perfected in Indin. According to the edherence of this branch, surtion was arpressed as the art of "devotion, of ldealiation, reached its highest development, and their consclousness attained freedom from the external plane, "17 the concept of rusic in sufism is beat expressed by DeVaut stating that "....elle purifte le seng, estelte 1 ine, repose l'esprit. fatt tressallir tous les nembes et facillte leurs nouvements. $\because 18$

Poetry is the very essence of the Hastern aystics, in expatiating on the "love to God." whis mystic poetry was first expounded upon by Ibn al-Waxtd of Egypt. and Ibn'ul-rArabi whose collections of ayatical wrtings influenced the works of Perstans and Turks Hike. 19 thus mystic poetry blossoned in tersie and bloomed in Asia as whole. Rexs4e tylng between the eroseroads of Elat and West, of India, Arabia, Egypt and Greece was influenced especially by these countrides' poetry und phllosophy, by sockates and pleto, and by thidutas as well as Budthlow. Hence Perte becane the tulting not fow these divergent ldeas and phllosophles and from whence suftsm took new shape and drection. It was in this area that the works of the famous aystics such as

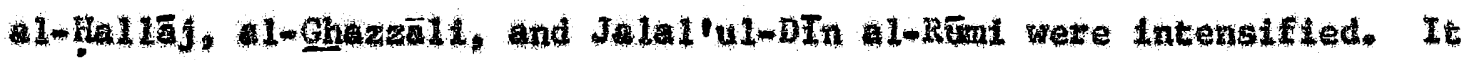
17khan, vol, vili, p. 14 .
18 Baron Garra Duvax, Les Bengeurs de Lingla (Paris: Libratrie Poul Geuthner, 1923), D. 239.

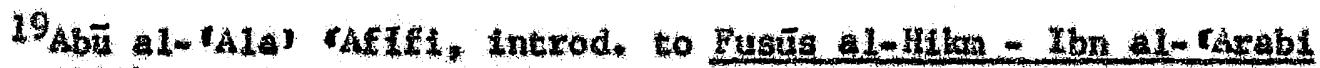
(Egpt, 1946), 18. 
was In As1a, In partieulax Iran. Iraq and India, where the Naqshobandi ordex flourlshed.

Islana and medieval Christianity touched each other on the common ground of mystctsn. The ascetlc life of monks ans emuloted by Sufis. The centul 1 deal of every Suti school, and the striving of every mystic, has been to reach the pexfecton which christ has taught in the Bible, "Be ye perfect. even as your Fother in heaven 15 perfect." 20

The Chrtstian intluence is best exhlbited in the teachings and writing of later mysties such as aI-Ha11aj. A1-Hallaj (Husayn Ibn Hansür, d. 922), Rerslan and a saintly ascetic was considered frivolous, trag ic, intelligent and devout man. He presched about the nature of God after he had atteined the ecstattc unton saytng "I am the Truth (Ana 1-Hagg)."21 Al-Hallaj's last prayer, uttered prior to a gorey, long executlon, is indlcative of his great and fervent desire throughout his life to "Die into God," offering himself as a sacrifice and following the axtople of Jesus:

Thóse who adote Thee, 0 God, have assembled here to k111 the out of theit love for Thee, so chat they ma come closer unto Thee. Pardon then, 0 Lord If Thou hast revealed to then whet thou hast revedled to me, they would not have done whet they have done; and if Thou hadst concesled from whe whou hast conceuled from them, I should not have suffered this tribulation. Hower and gloxy unto thee in whatsoever Thou whest 22

20than, vol. vili, p. 18.

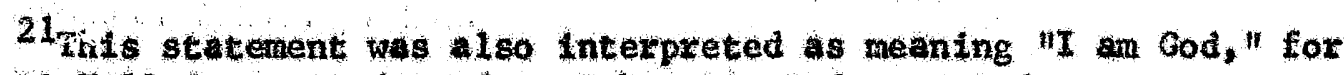
which $1-$ Hallaj was condenned as a heretic and executed.

22Robet Reyne, The Holy Sword (New York: Co114ex Books, 1962), pp. 219-220. This quotation also appers in Louls Missignon \& Pav1 Kraus, Akhbar a1-Hailel, Arabic-French text (France: Imprimerie "Au Calane, $7(936), p \cdot 7$. 
Inelly, in the words of Str thomas Arnold. "The homge paid to the Prophet by rany of the new schools cannot hide the fact that their spiritual home is not Mecca but Athens and Alexundr La. "23

Suflam structured Islonie soclety politically, socielly and religlously. The society had to contend also with internal as well as external pressures. The external pressures stemed from the Invasion by Mongols. The Internal pressures stemed froth the sharifah (jurists) who wanted to find a law for every tritle thing in man's day to day living in order to give it meaning and form. Too much emphasis was placed by the jurfsts on rationality. The seciety felt these pressures and consequenty man found an escape in sufison. By rebelling against the forndities of the jurists, they gave the individual more freedon in reestablishing his relationship of man to men, and of man to God. Thus suflom fultilied and answered deep emotiona1, relfgious, and social need of the tine, be it escapism on one hand or a sincere desire to know god on the other. 
TLE EIISILA AND BTOGAPHCAE ASPECT

OF THE NAQSHABANDI ORDER

CHAPTER II

The Sufls are generally in aggeenent as to the early generations of dilslle of chain of hlerorchical spirftud transference. This gives the Institution of Islam some fuston and order from which the divisions and sub-divisions of dervish orders held the thread of Inner 1lght, such as grace or betakeh (blessing), which guides them long their path. The lineage is considered in the following descendIng ordex; Allah (God), Jibreyl1 (Angel Gabriel), Whhmod (The Prophet), (ALI (Fourth Callph), and Abr Bakr (First Caliph). ${ }^{1}$ Muhemad was considered by nost orders as the first Sufi. After him, according to Nasf, the "representative par excellence of Islanic esoterleisa (1s) rali Ibn'AbT TöLb, ${ }^{2}$ Most of the SuCt orders trace their origin to the first Inam, CAII, while many of the later Suf1 sects were disciples of verious Inüns, espectally the stxth Imö, Jeffer al-șādiq $(88 / 702-148 / 765)$ and the eighth Imbm, MlI al-RIda (around 148/765 203/818). 3 In other words, the emphasts of the silsile is placed first on the person of the Prophet, second, on the four oxthodox ealiphs, espectelly'AbI Bakr and rAlt Ibn'AbI Télib, third, on the

\footnotetext{
1John R. Brown, The Dervishes (London: Trubnex Co, 1868), p. 49.

2Nasx, p. 83. This statement might have an elenent of bias since Nasx is a Shi'e.

3ibla, pp. $85-6$.
} 
Companions and the Compantons of the Companions, and last on the breat mystics of the ages.

The S11st1as of the Ordex

There are several interpretations and variations as to the

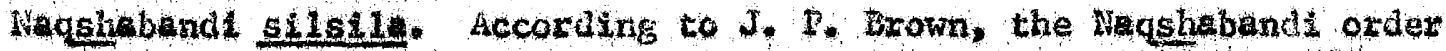
is one of the "twalve orfgind dervish orders" trecing its inception to 'AbI Bekr dI-SiddI, one of the Prophet's Cirst Caliphs, the Frophet stated, Whatever God poured in my heart, I in turn poured It In the heart of 'AbT-Bakr. $0^{4}$

Another source clatns that the Nighobandi order had tho branches: one sterming from'AbI Batk and the other elatms spiritual connection through the Iineage of All and is called the "golden." This source further asserts that the two brunches met in the great Inann, 1-shaykh CAbd-al-Lha1iq a1-Ghajdawäni (d. 575/1179-80) to whose 1eadership the Kaqshaband order is Indebted in its strength and affusion. 5 he was considered a huble man that observed religtously the laws which made up Is lat and the order, a guatuty which is desired For craslation by the muric.

The nost profound interpotation encounceres on the taqshabandi

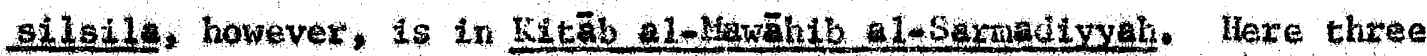

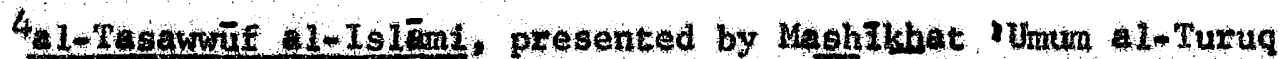
a1-Suftyyat (Cbiro: n.d.), p. 25. This is complied by the shaykhs of the vartous tarlqas. There are no dequate Arabic and English sources to substantiate this stetenent in order to pass judgergent on whether it Lt valld or a counter attack of Shila assertions.

5ibid., p. 26 . 


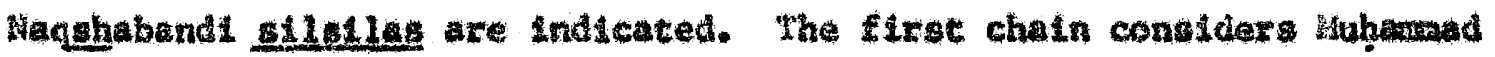

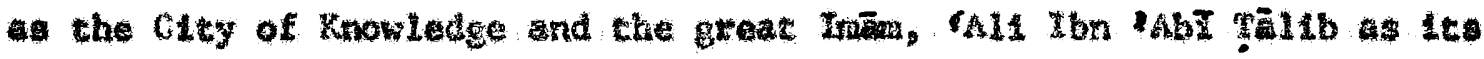

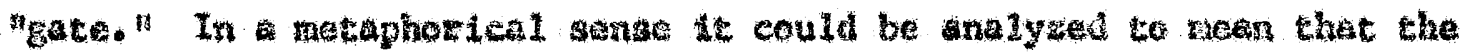

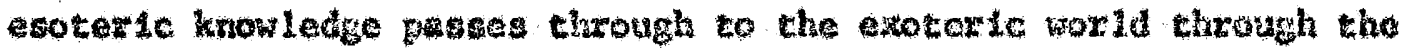
peran of M1I. Fot this maln concept not only syobolizes the marting of the Inner knowledge fron one betng to another but also laplant 1 in the pergon of the murghd (splritul gutde) wall. whe linedge after 11 is stated as follows:

To the lord of teartyrs, AbI Abdullah

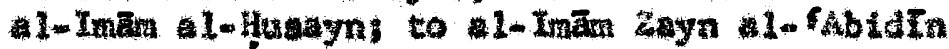
AlI, to al-Iman Muhanead 1-Bagix; to

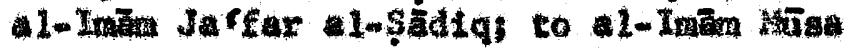
1-Kädbin: to 1-Inin rali al-kiga; to

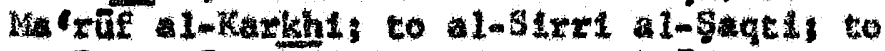
Abz al-Qãein al-Junayd al-Bahdëdi; to

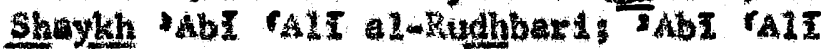

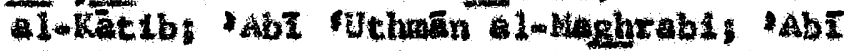

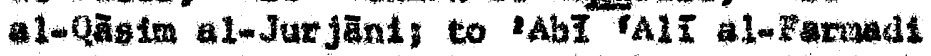
cheykh of the third chatn which is called the golden once...

It is colled "golden" becuse it is connected to the "quretifed hone,"

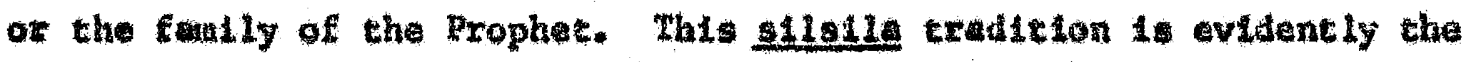
origin for one of the forementionet interpreteitons.

Taking second look the ftrst ching, one can see the in

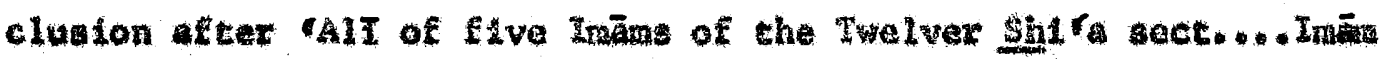

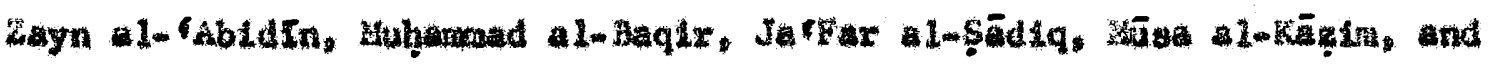
AII I-Flda. It can be asserted that prlow to the seventh Imain,

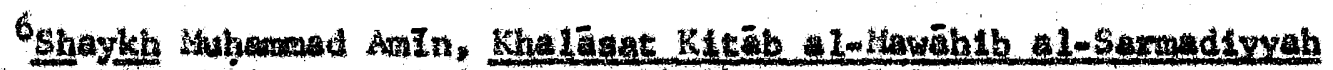
(no place of pubilcation indeated, 1958), pp. 7-3. 


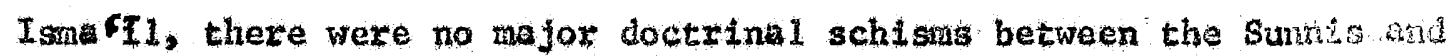
Shtris save polfttcal, nost important of which was the successorship of the Prophet.

The second chatn constders tuhamad as the Splrit of the World followed by the "prince of bellevers, " tal. Then to

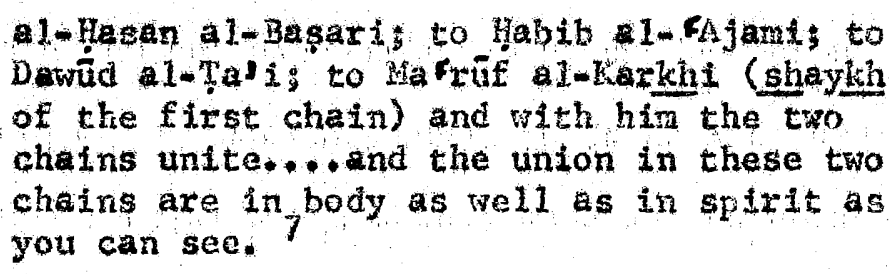

And the third chaln clatus Ineage from the "itord of Existence"

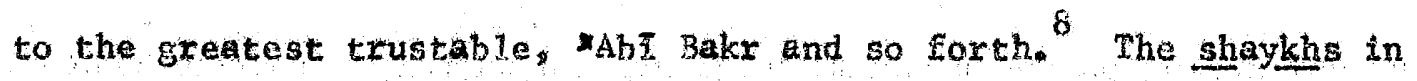
this third chain used to discuss the gixts and means of worship as well os their lineage vithout denying the flist two chains. The spixitual attainments in this chain stpercede that of the actual physical lineage due to the dignty of God which is nore appreciated and understood by the shaykhs and by all humanty. 9 one cen deduce that 3. P. Brown gained Inpetus for lat interpretation of the orderis \$11sile from the third chatn.

The discusston so far constitutes the spititual connection of the silsila. This is very stgntficant but tast be implemented by the blographies of known shayhs in ordet to have fusion in the chain,

\section{Ibid., p. 8 . \\ Inia. \\ 9 Ibid. $p$ p. 8.9}


wabreakable, and to have a model arer which the wurid can pattern his actions to achieve spirstual vixtue. This virtue perueates the igures

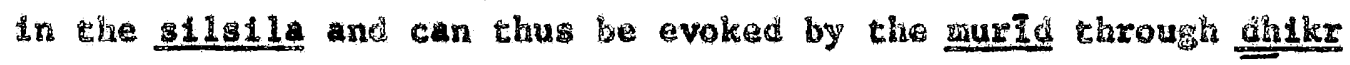
(Ittany) and contemplation.

Guhamad Gaha al-OLn al- Hukhari

The earliest traceable Hography ${ }^{10}$ and ante of inception that is

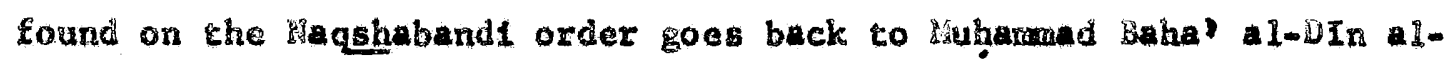
Bukhär $(717 / 1317$ - 791/1389). He is considered the founder of the order, and It 1 said that it was he who had collected the sayings of al-Ghajoawani. 11. J. P. Brown's authoritative study of the dervishes Interprets his name, which signifles "painter," as "drawing incomparable pictures of the Divine science." He quotes Dellerbilot's interpretation that "Naqghibend" is his surname (patronimic) and the author of several works among which is the "Makamat" (lectures) dealing bith various subjects. 12

A1-Bukhäri was born In a vilage called Kughk Hhâuwān, latez Kushk Arifän near Bukhara in 01d Fersia. At 18 he went to branas to learn sulsm frow Muthamad Bahat-al-gamäst. In hls systen bhe dhikr was rectted aloud; Maqshaband preferred that of Abu-al-Khalig alGhajdawani who rectced it silently. however, the adherents of

10 See Appendix

11. The incyclopedia of Islaw, edited by M. T. Houtsma, A. S. Wensinck, et a (Leiden: L. Jo Bri11, 1936, volo ili, ist ej.), article on Naqshabandi Oxder, p.84.

12 Brown, pp. 124-125. Makaraét here does not refer to "stages" of spiritual ascendence. 


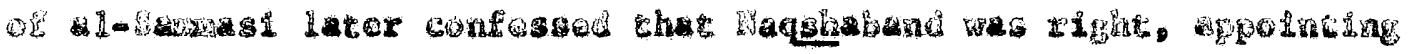

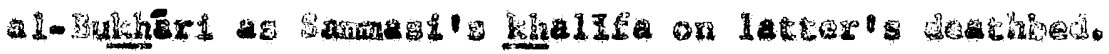

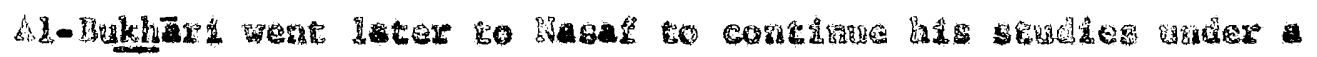

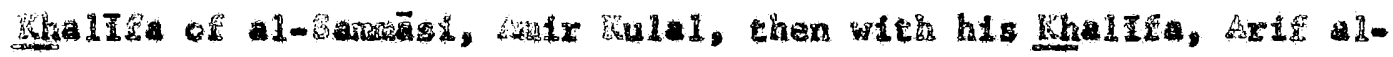

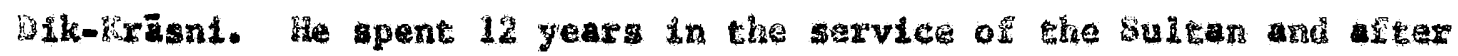
the monarch" fall he "practiced philanthropy and the care of andents

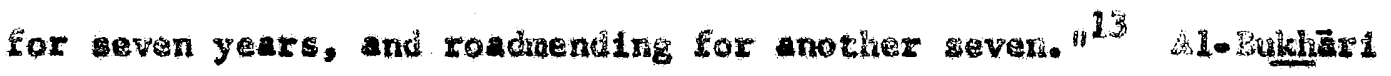

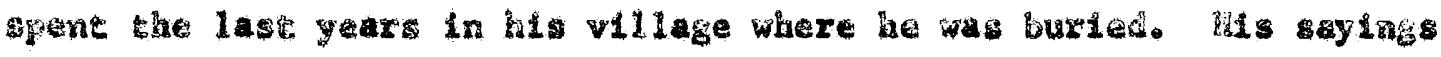

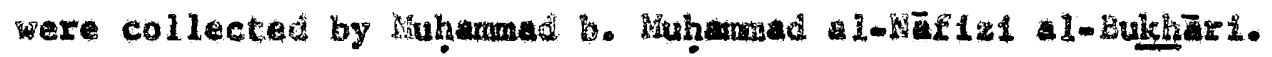

\section{Shaykl Khalld al-Shahragurl al-Nagshaband}

15 later known blography of a siquhaband, who is constered to dave restored the order, 1 of the lghtenth century by the rane of

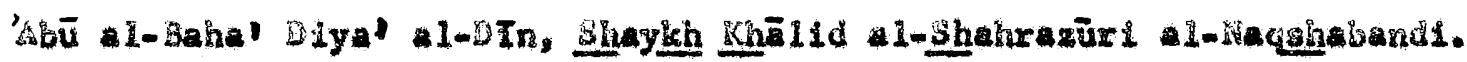

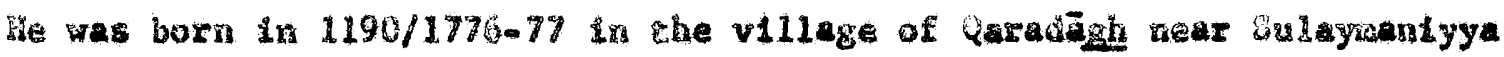
In Iraq̨. After his early studles in qaradāgh, followed by perion of Intermitcent craveling in search of knowledge, fas setcled in Bulaymantyya. Even chough news of his learning and undergtanding

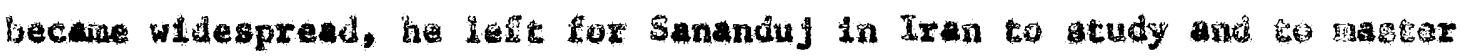

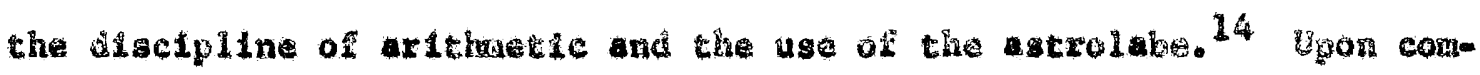

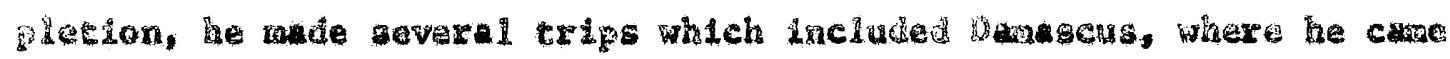

13 Inerclopedin, vol. 21, 241.

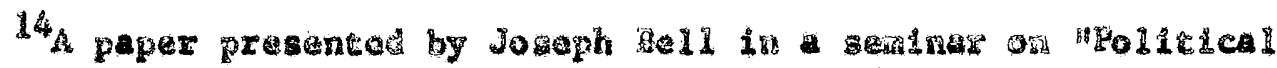

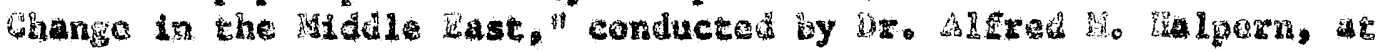

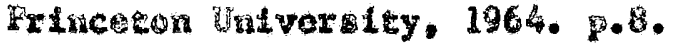


In contact with Shafili tradicions, and Mecca. Following his return to Sulaymaniyya, Khälld was seeking a murshid and was to ld thac o grent holy man who could assist him was Thanal al-DIn al-Naqshabandi who IIved in Delhi and was referred to as Shaykh al-Nighayihh (a Sufl's title of Shaykh of shaykhs) of India. ${ }^{15}$ He left for Delhi in the year 1224/1809- 10 .

He was Initiated into the Naqshaband tariga (path) in less than five months and became one of the "Ahl al-Hudur wall-Kughēhada. 16 Abd Allah al-Dihlawl, who referred khälld to the shaykh al-kashäylkh, licensed Khälid in "mystical guidence and made him his fully authorized vicar or successor (khalifa) in the following five orders: Haqghabandiya, Qidiriya, Suhrawardiya, Kubrawiya, and Chishtiya, 1 if the returned to Iraq to propagate the Naqhabandi order, after which a number of social conflicts resulted in khälid's departure to Syria, in 1238/1822-23, where 1t flourlshed.

dachshabandi Shaykhs in Egypt

According to Shaykh Sayyid al-Nuwwār, the Naqghabandi order cane to Egypt about 1900 through Damascrs and Shaykh Muhamnad Gouda, the flrst Egyptian Naqghaband, was burled in Ninyat al-Qamh. FAziyyah, Minyat al-Qumh and other nearby villages are today dorainantly

\section{Ibld.}

16Ibid., p. 9. The quote refers to people who had seen and werce in the presence of Sod.

17 Ibia. 
Naqshabandi. Although the shaykhs during bhaykh Gouda's tuile devotad their entire energies to religious endeavors, subsequent shaykhs followed other professions. This stems from the increasing coxplexity of the social structure and the demends placed by it on men. For example, today's Shaykh Armad, 18 a traveling merchant, receives two or three hundred Egyptian pounds a year for belng the order's religlous leader. It is also comon practice for the cut-of-tom muridin (novices) to bxing him butcer, fice, chicken, fiour, depening on their livelihood.

No mattex whether the shaykh or murshid is a devout and rellgious ascetc or one that is partially worldly and devotes sowe energies to the attainment of 1 ffe's necessities as is generally the case now in Egypt and eisewhere, and, according to the Naqshabanai doctrine, it is very laportant to know something abouk the preceding sliayklis. The fact is that the nurid (novice) could not reach a spiritual association or esoteric ffiliation between himself and those that preceded him unless he knows something wout them -... their reachings, chaxacter and way of life -... in order to nodel himself after them, fain stated that the murid wust walk their paths and do their works. 19 Thus, to know the virtues of the preceding-shaykhs night be more inportant for the follower than seeing them because the

$$
\begin{aligned}
& 10_{\text {The Eull name of Shaykh Almad was unattainable. }} \\
& { }^{19} \text { Anin, p. } 5 \text {. }
\end{aligned}
$$


murid mighe be hindered irod penerrating the "delicute secrets" of the gurshid's soul by their physical appearance.

The Naqshaband teachings also stress that a gurid nust attach himself to the murshid, who is the heir of Wuhamad and through whom God manifests His presence uninterruptedly in the gilsila. It is paramount, therefore, for the murid to attach hinself to shaykh and to serve hin with devout belief, faithfulness and sincerity. 20 The moral conduct of the murld is also stressed, he must practice good behavior and virtues and avoid vices. By doing so, the murid will ascend to the degree of contemplating cod and hearing hion in the same way that the benevolent saints ('awliyal), the good believers and especially the Naqshabandl masters had done. Furthermore, it is essential for the murId to attach himself to a murshid, to protect this relationship, and to make the gurshid his spiritual gulde, living with him, and practicing the doctrinal rituals. The characteristics of the shaykh and his spiritual moods are then transmitted gradually to him and whatever the murshid has of perfection in spirit it is also reflected in the murId. This attachment w111 result in the raurid's spiritual development and virtue which is the first step in transcending the silsila to God.

20 Ibid., p. 6. 
The Naqshaband coctrine rests on the premise that the purpose Lot the creation of man in shis life is to fulfil worshipging God Whout any intermediarles. As long as man is in the presence of cod and full of love cowards Ha, he attains this end. The Naquabandis clatin that their means of worshif Is the "nearest and eastege" for the follower to achieve the highest level of reaching unton the God."

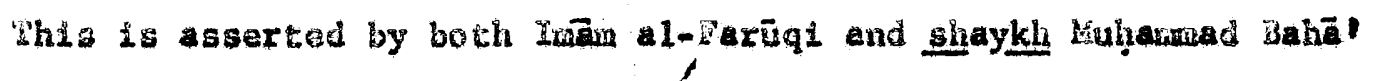
al-Din a 1-Naqghaband1. 2

Worshipping is not only spiritual but has physical characteristics as well in the presence of God. These outer signs are manifostations of the ecstasy of the Union. Those who attained this divine Union would strike the ground, or would cry our like l-kiliaj "I ari the Truth." As was scated earlier, the object of the gath in atcan Ing union with God is to lose one's own ldentity and find oneself in God. Dolng so, perfection is actained by the rarid. Sufl doetrine of the divine union is undoubtedly influenced by Grahnus, Buddhtos, Neo-Flatonists and others. ${ }^{3}$ The conanation of all things frow Cod and their final absorption by Hia, through which man loses ois incividual

$1_{\text {dtan }}$, p. 7. This chapter is mainly taken from dain's, 登ftab al-Mawahib al-Barmadiyvah, pp. $162-192$.

In10.

3richolson, Literary, 13.34. 


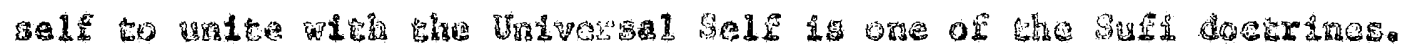

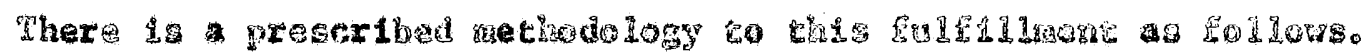

\section{Nagshabandi Inttiation}

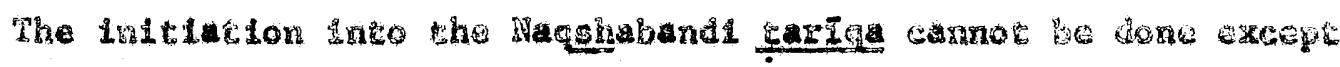

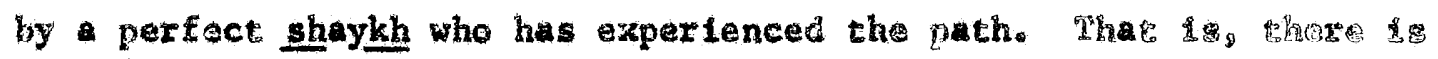
no way in entering the washaband otue other chan through che reane of Instruction by an expert and wise ghoyleh. The secret a fingeruc-

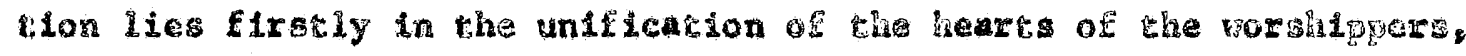

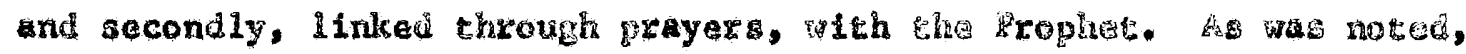

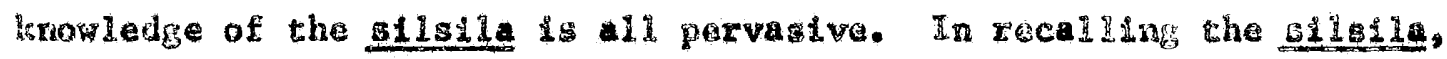
by grayers, the splrits of the saines and shaykhs, the initiatars, will Ink the Prophet, all regyonding to the prayers of the troe thever. other major concegts of the ianshaband lnstuction are che concegt of Lepentance, Dhlkr, and krayers of the hasters.

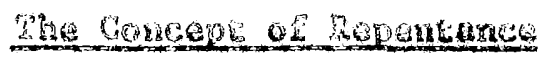

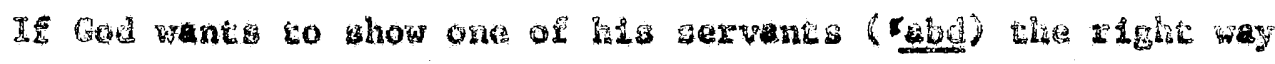

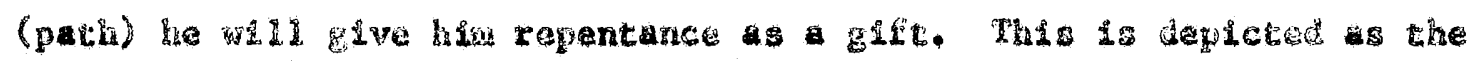

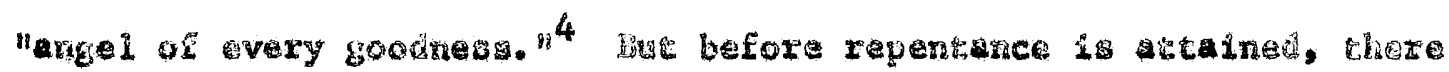

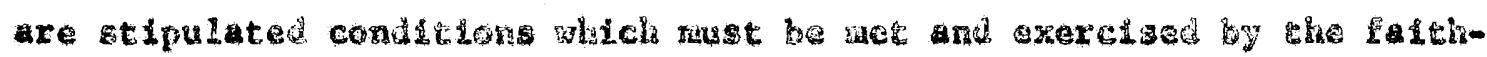
ful: Regretting - past disobedience towards God; Macernindtion - In

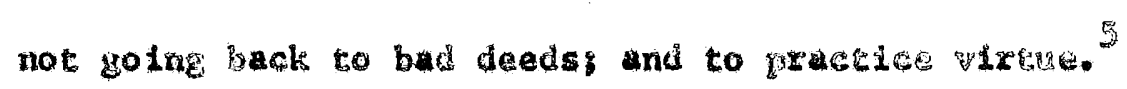

\footnotetext{
${ }^{4}$ bid., p. 166 .

Ibid.
} 


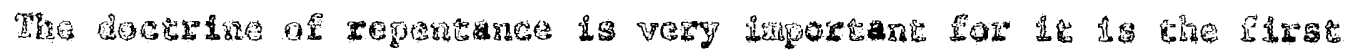

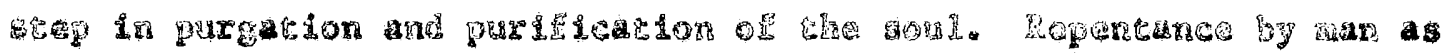

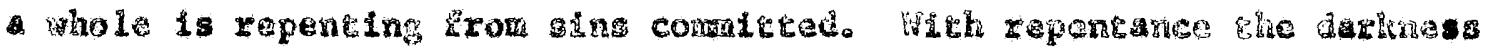

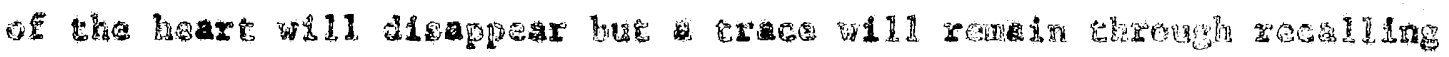

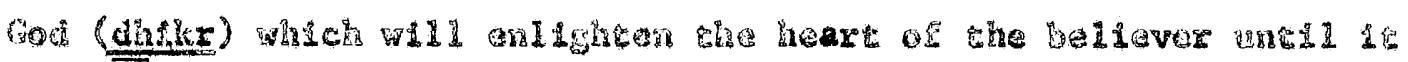
becones like a lamp. Because of its light bhe good norals are ate-

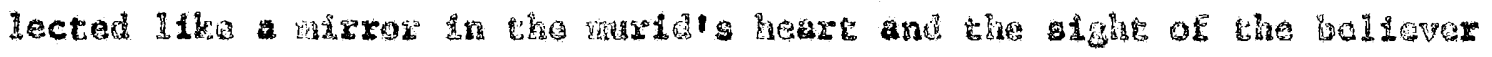

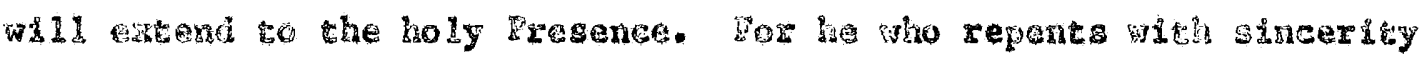

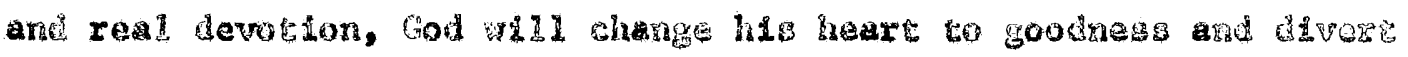

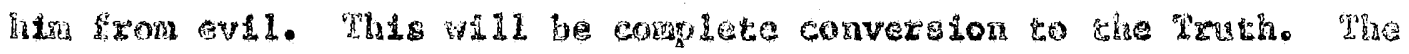

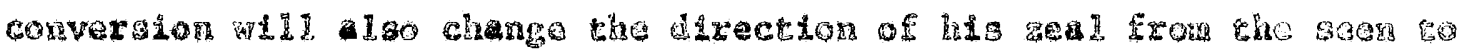

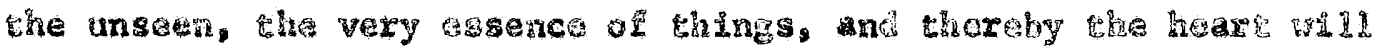

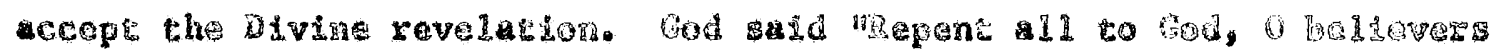

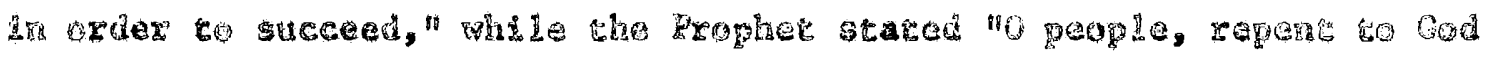

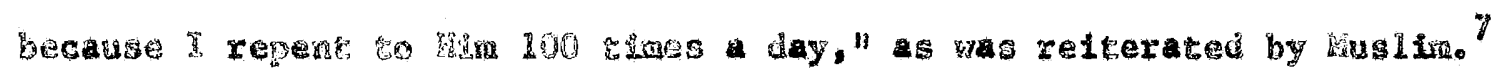

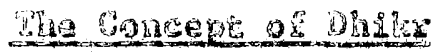

E⿱

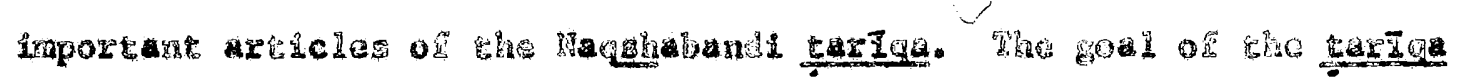
1.

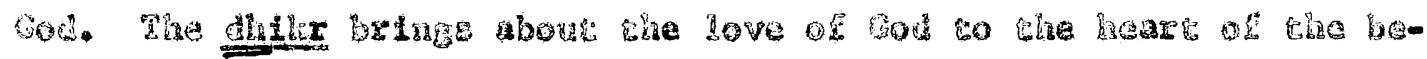

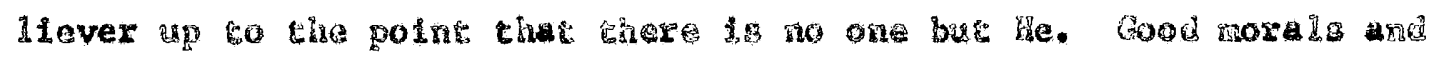

Gaxn, p. 166.

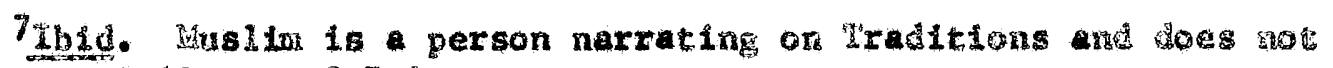

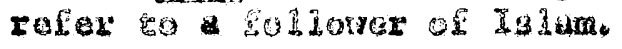




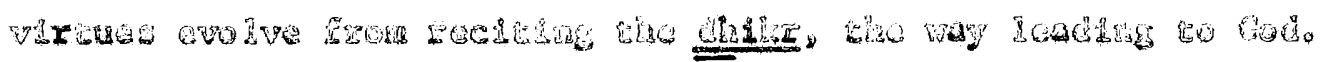

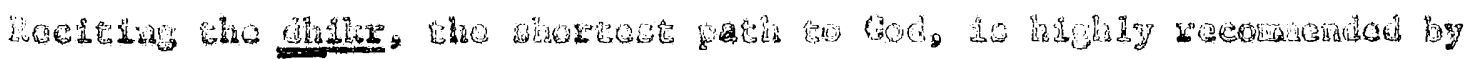

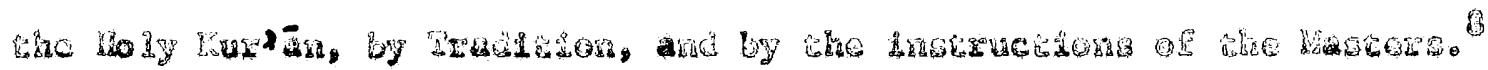

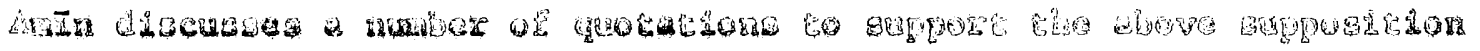

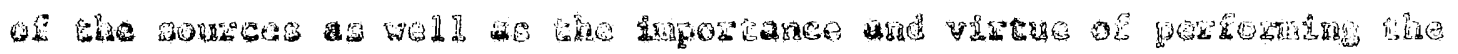

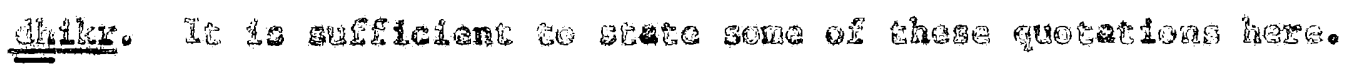

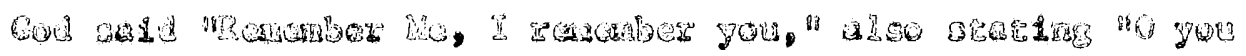

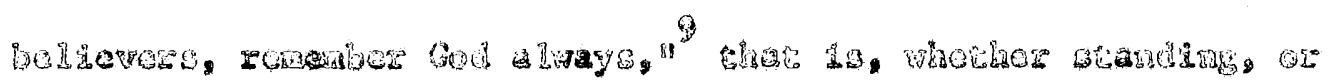

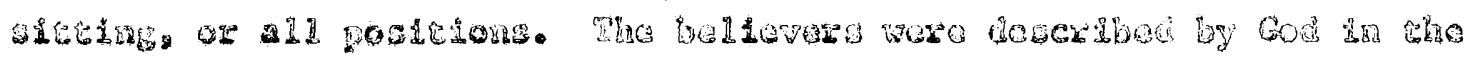

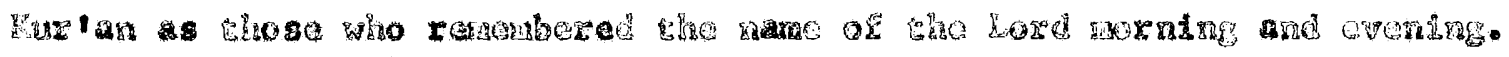

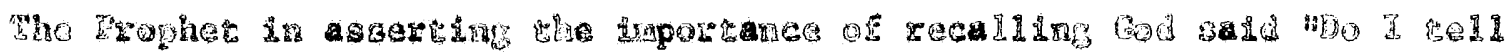

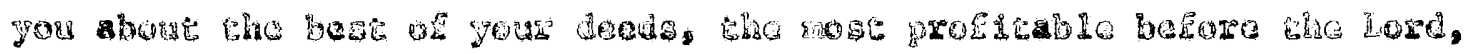

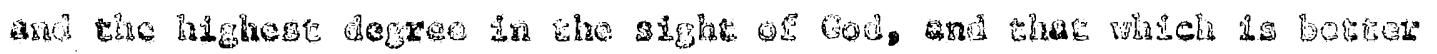

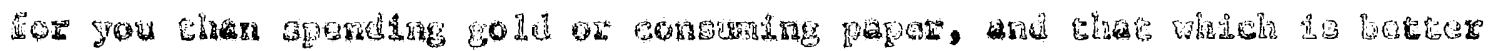

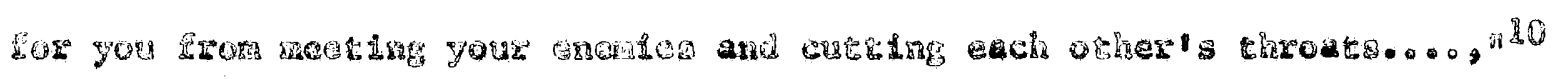

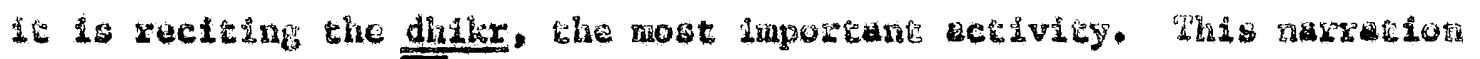

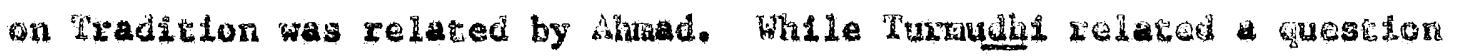

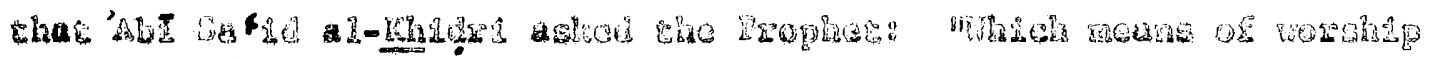

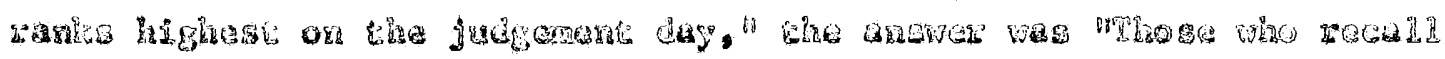

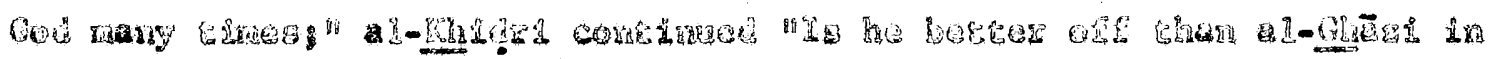

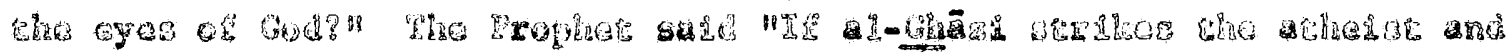

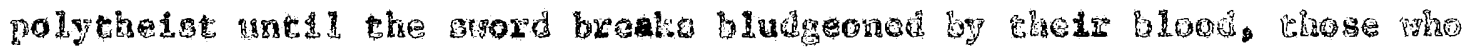

8.

ILI

$10 \mathrm{Ib}$ 


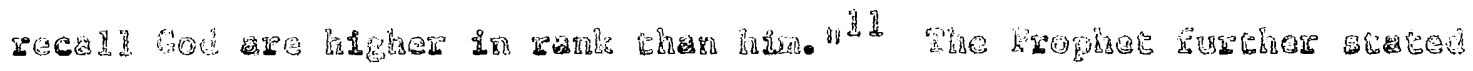

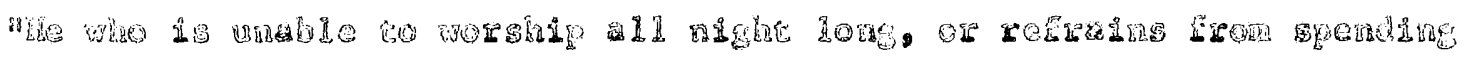

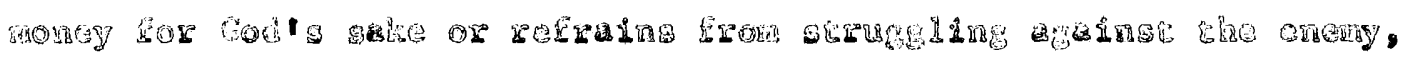

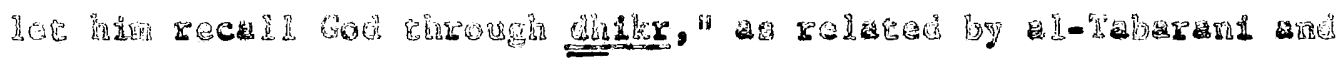

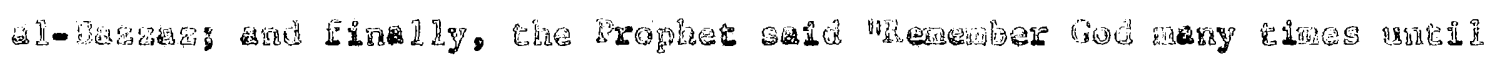

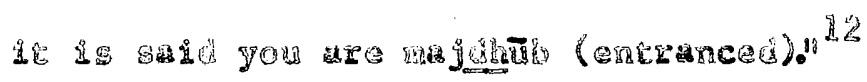

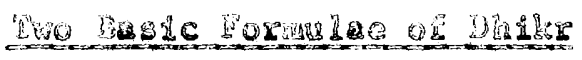

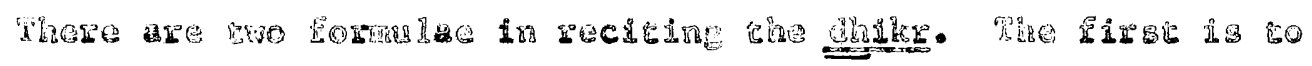

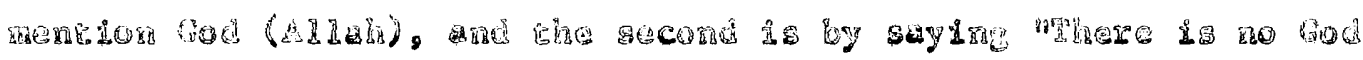

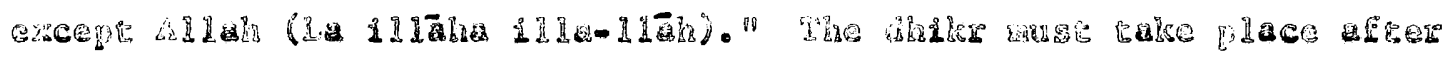

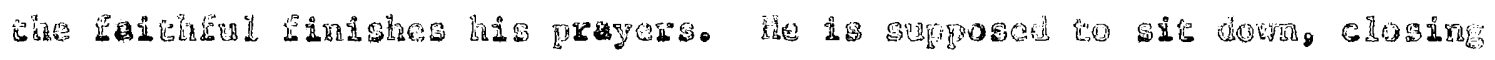

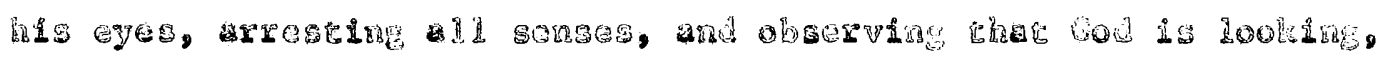

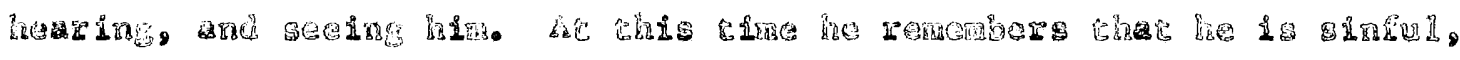

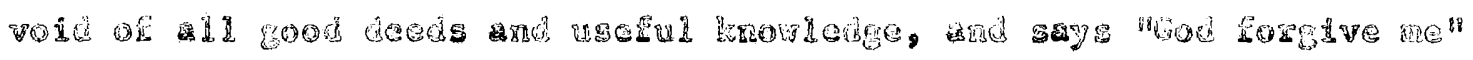

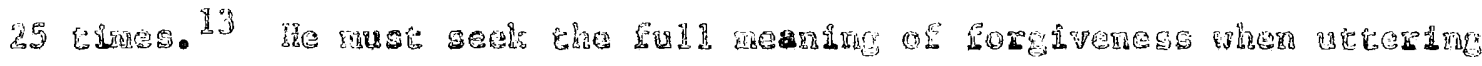

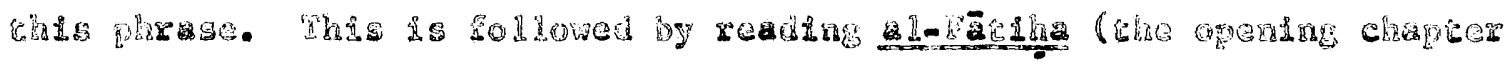
of the rar

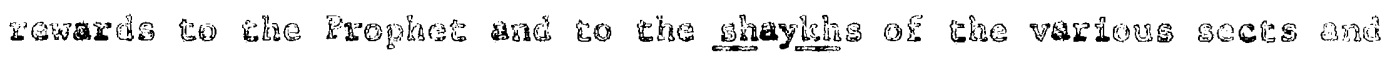

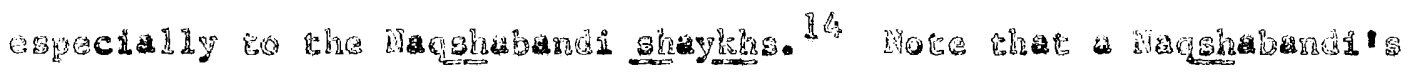

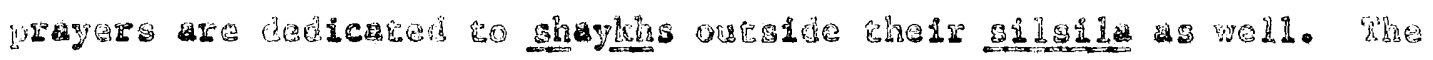

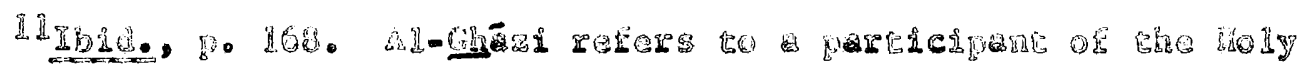

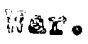

129.96

I3ISe, we 177 .

(3)
} 


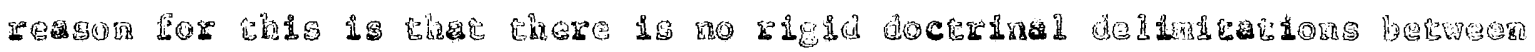

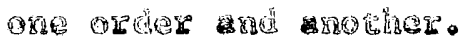

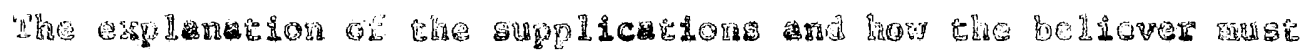

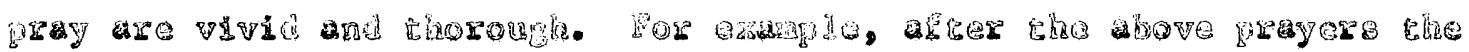

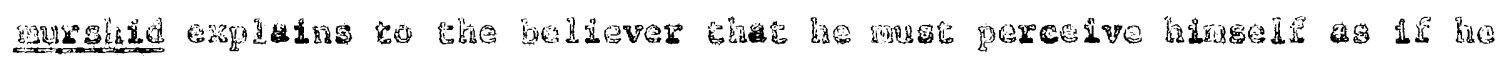

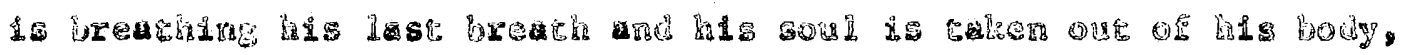
A

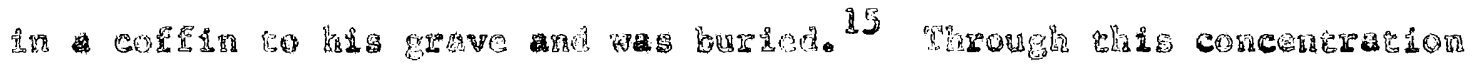

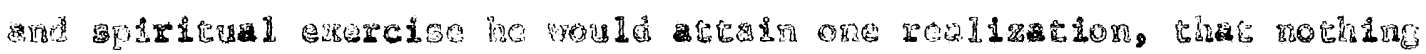

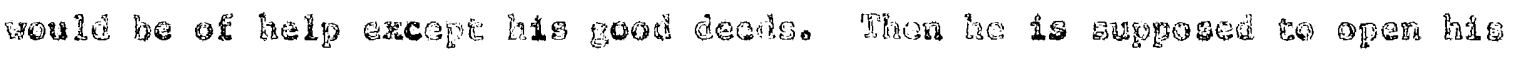

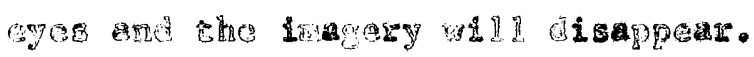

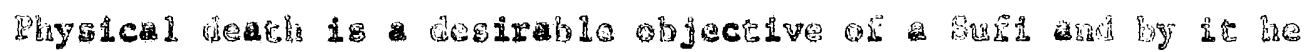

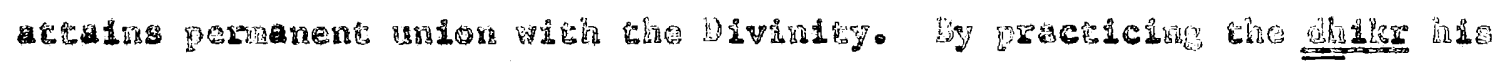

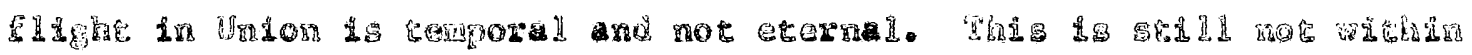

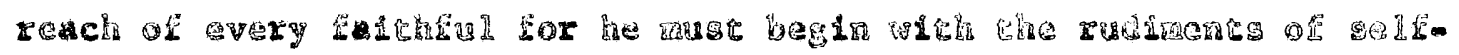

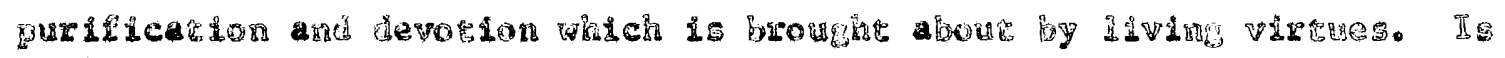

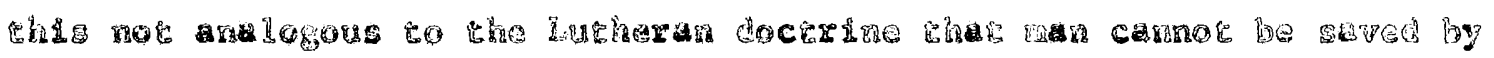

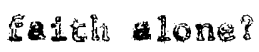

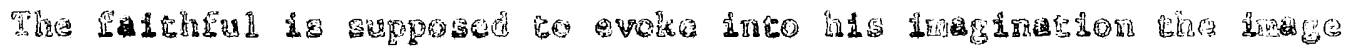

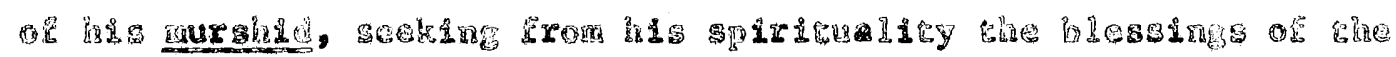

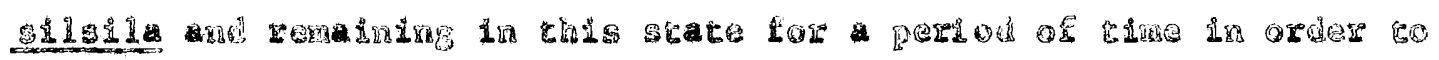

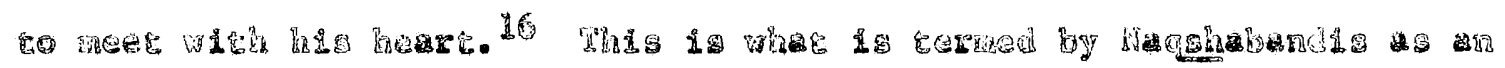

\section{I5ged. \\ 16 I 1 .}


-

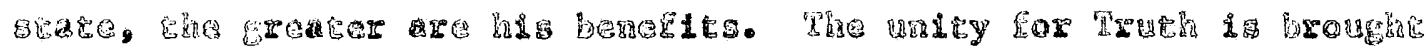

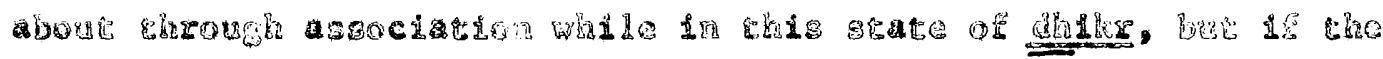
yut PEs

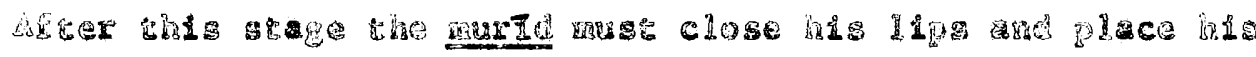

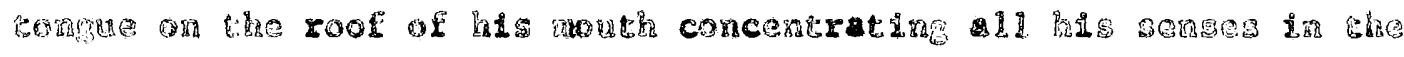

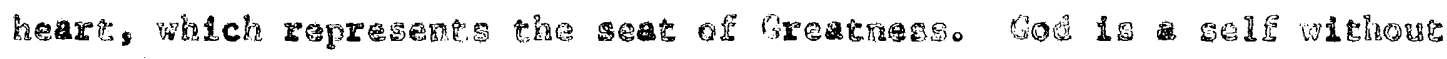

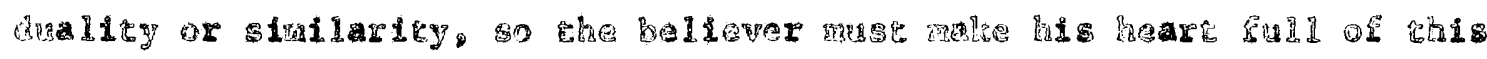

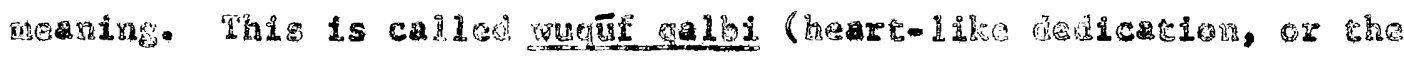

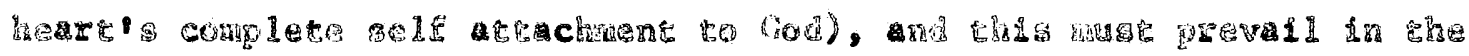

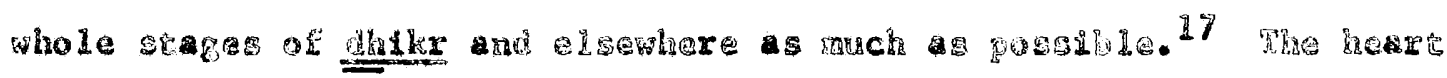

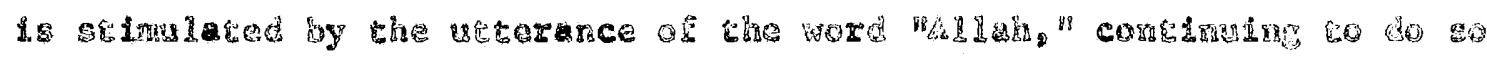

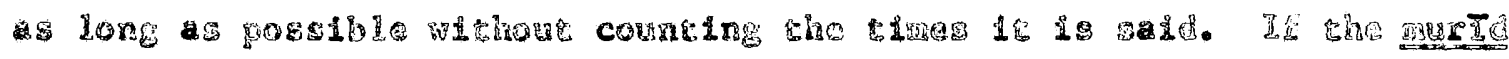

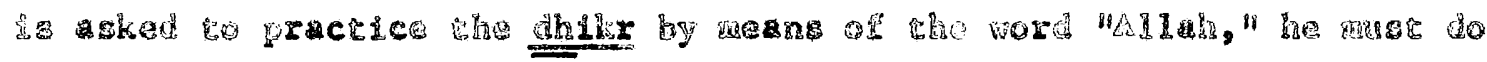

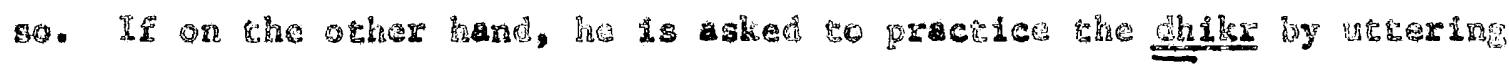

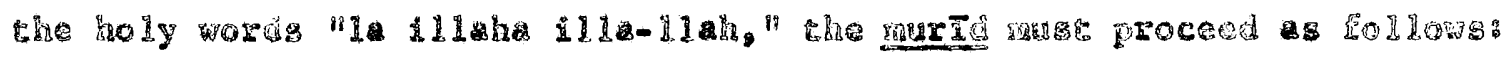

trrest your breach below the nuval ane refrebh

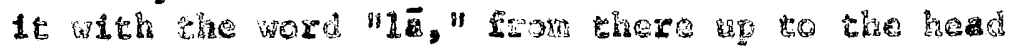

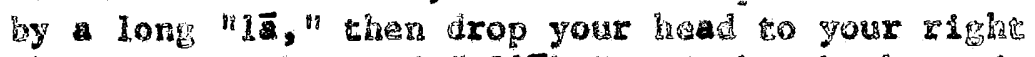
shoulder hy the wor "III "1.

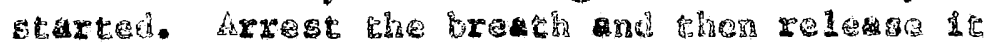
atter one repetition or three or iwe ciras. beser the releas of evary breach you suy rish yont

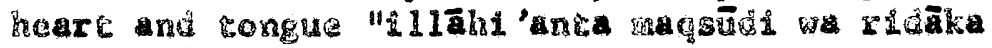

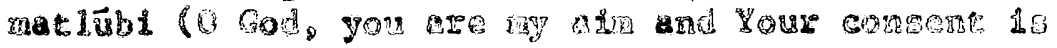

17 DE. 


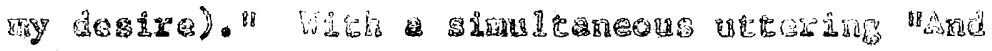

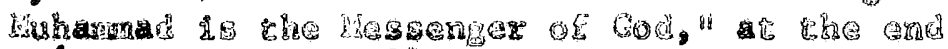
of overy bresch. In

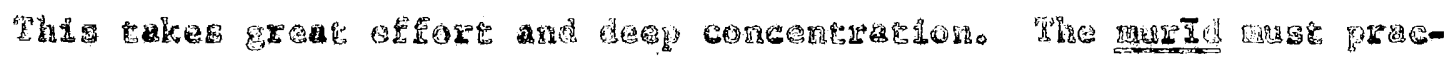

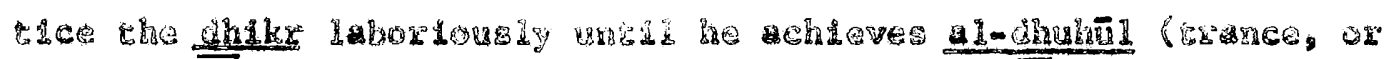

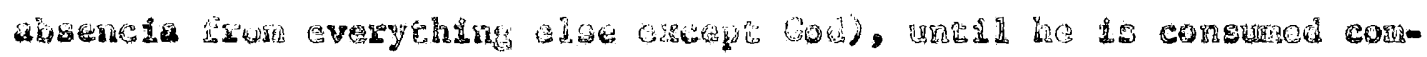

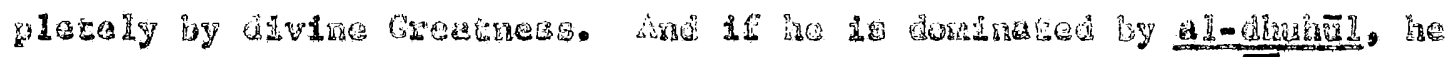

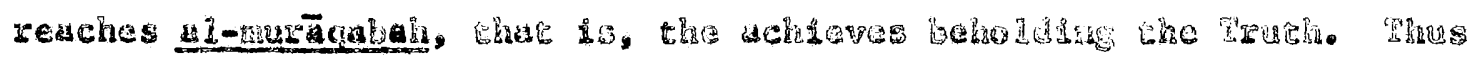

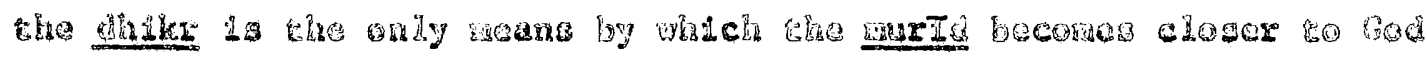

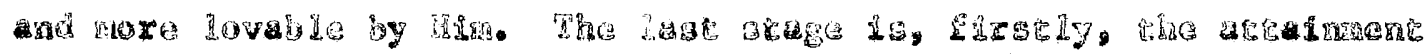

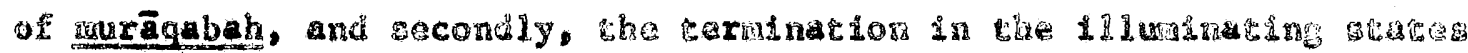

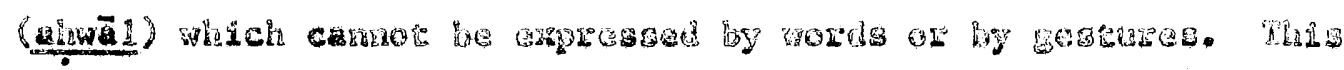

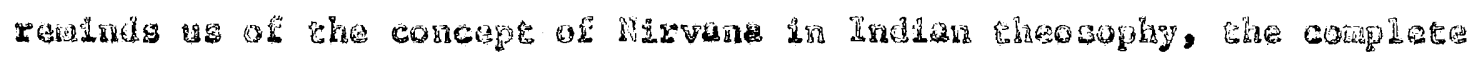
rocura ro Gors.

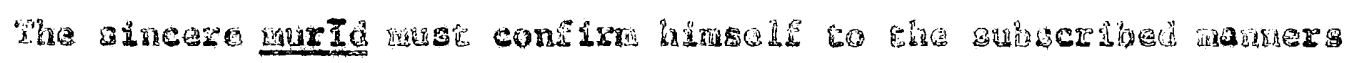

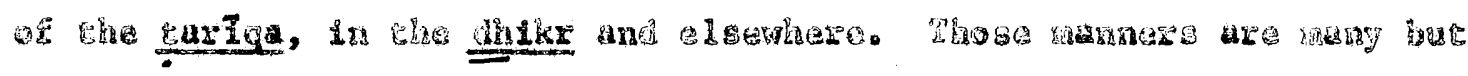

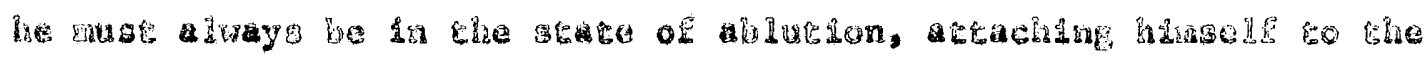

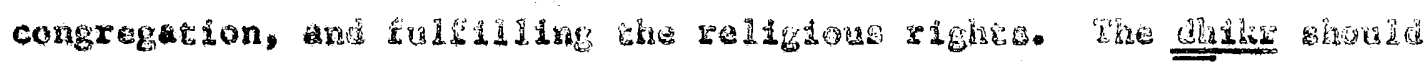

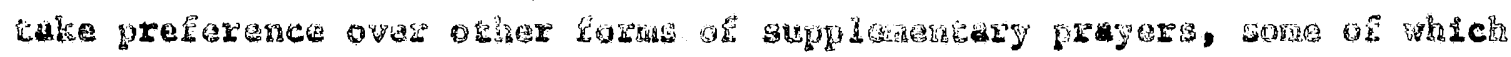

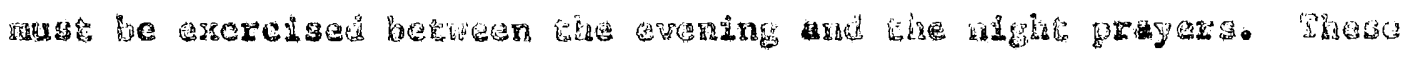

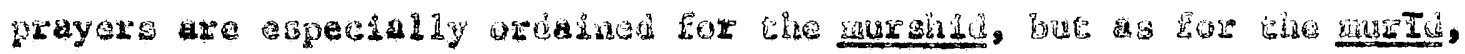

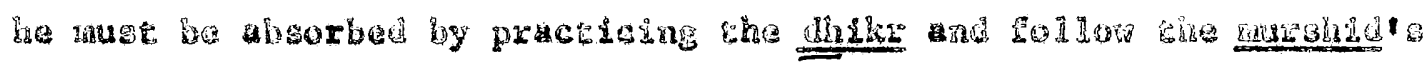

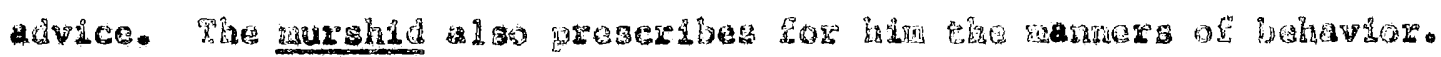

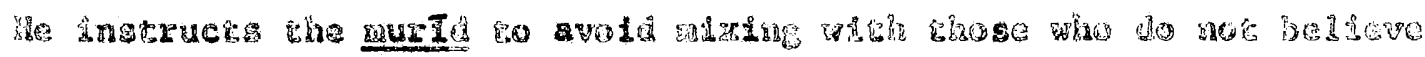


in the tariga, because such a relationshly will result in the severity

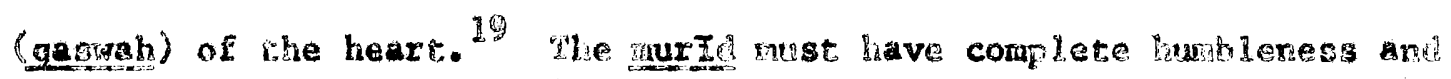
he must always seek the righteous path befauge those who to otherwise will not reach the Truth.

\section{al-Jacheah}

It is dificult to render full significance to the tera "al-jadhbal" other than signifying, Iiterally, that it is being "attracted" co God, i.e., entranced. It is a bufl state of deserting the world and being attracted completely by God. This state is sfruly rendered in inglish as the "trance."

The jadhbah was a controversial issue between the Suflis and jurists, the latter denied such a state and accused the Susis of hypocrisy. Whatever the controverstes may be the Sufis content that folis is the esserce of the dhikr. The jaghbah is not within the reach of every believer, it Is a natural consequence only if the bellaver has humble heart, is

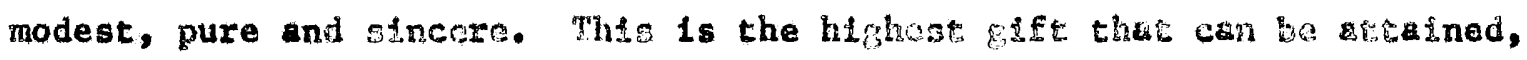
to be in the Divine presence. The Prophet gatd regarding those who do belleve in the jaghbah "Ood I take refure with whee from the those heart does not fear." 20

The Sufis, in counter-attacking the furists' denial of the jadhbeh and In order to cement their position, attempted to recount stories frows

$$
\begin{aligned}
& 19 \text { Ibld., p. } 179 . \\
& 20 \text { Ib1de, p. } 190 .
\end{aligned}
$$


"20

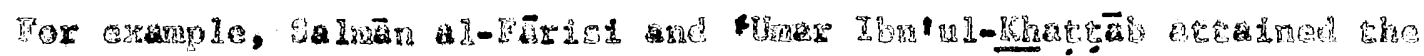

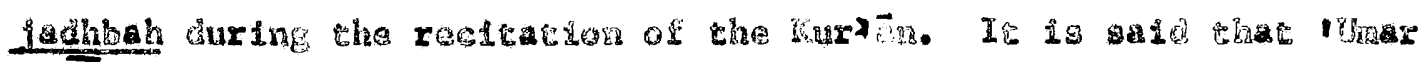

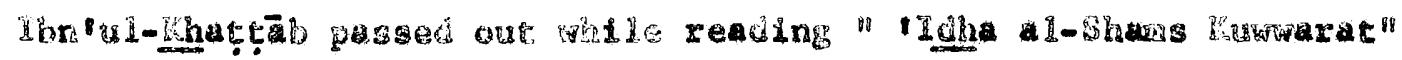

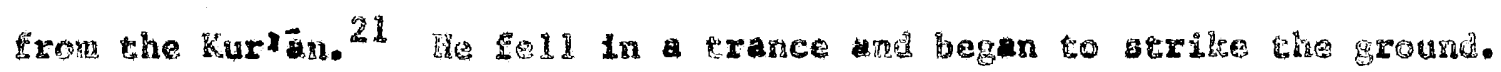
Salmān al-Wälsi, orb the other hand, ackined the jadbbah whle reading

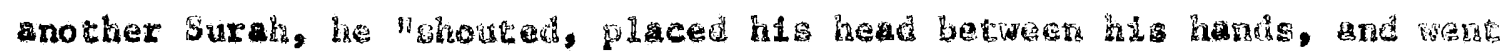

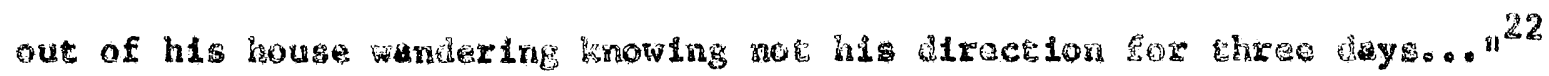

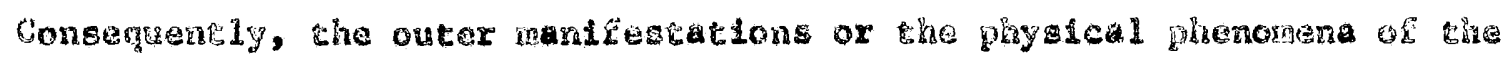

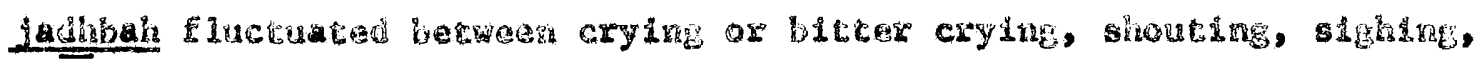
crabling, stiking the ground, and wandering on the face of the earcti

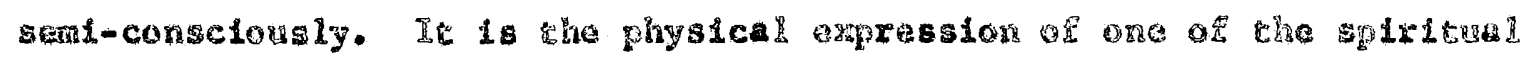
seateg of the gufis. It is crossing the borders between the physical and the aecaphysical realras.

Whe state of the jadhab is analogous to a state of a person

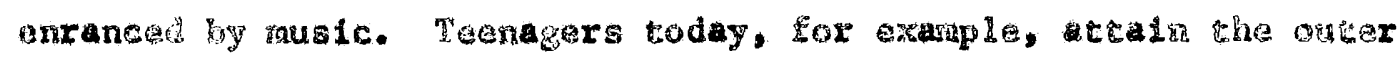

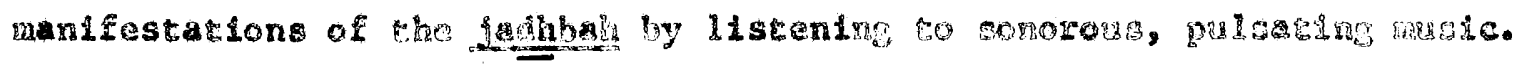
While the Maqshabardis, on the other harh, reach it methodicaly ard

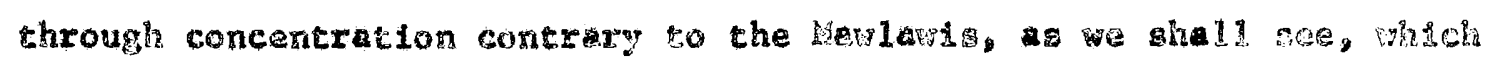
is closer to rhe former. Wht

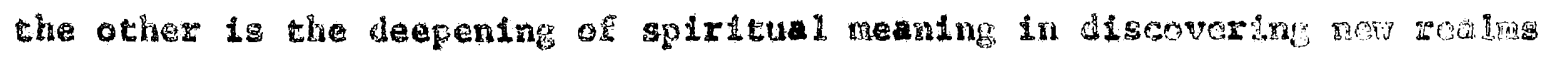
af the soul. Th1s elevates the person to higher levels of spiritualiby.

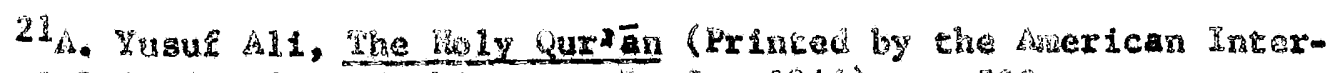
mational Princine Co., Waghingen, L. C., 1948 , p. 50 . 22 Masn, 190. 


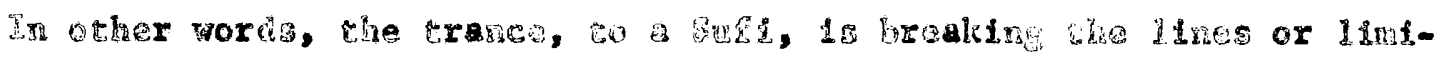

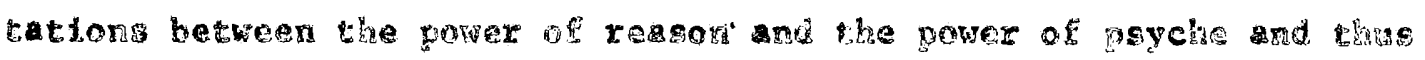
being occupled with the one notion, the comanion whe the overom.

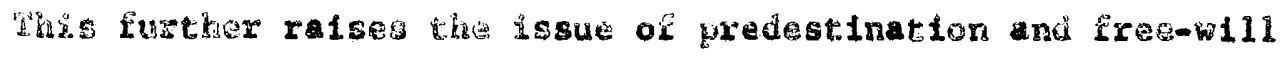
between the jurists and the Sufis. The jurists intain that he who attains che Juhbah has no free chalce and Gius wating the controversid guestion, do the wajherb (entrancel) preserve his reason of is ho

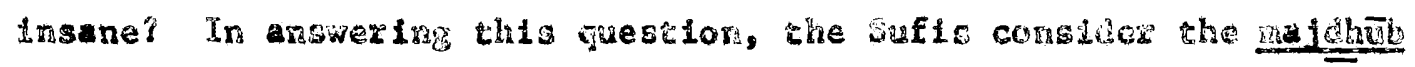
us pertect being because of his communion with God.

\section{Pravers of the inseers}

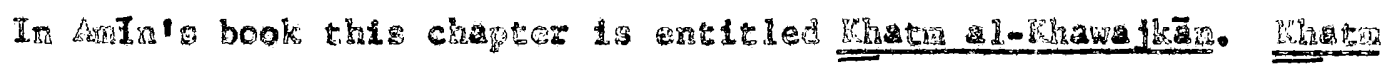
Heans the "ggal" or "ending" prayers of the Wagterg (Khawa1k- 2 ). 23 Collectuoly the ending prayers are spectal, set ritual by which the ahike fo closed. The specific prayer take place inursilay or Hondy, dey or nderte.

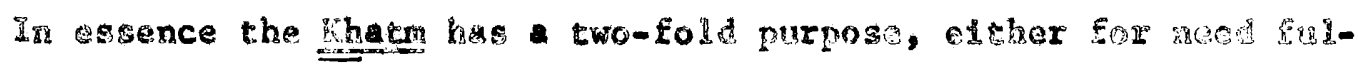

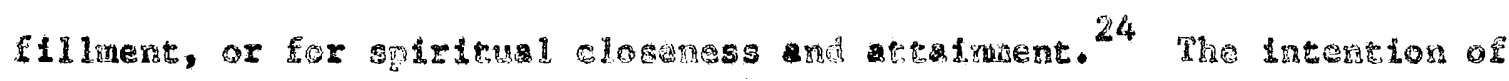
the prayex is to invole the transmittal of the blessings of the silsila and of the shaykhs to the morId and the bellever in genereng in garticular, to bring certain needs and wishes for fulfillarent and zealization.

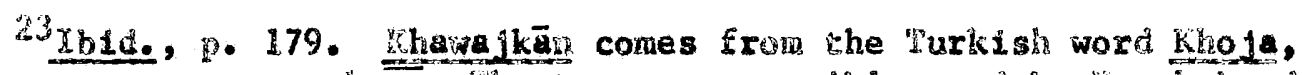

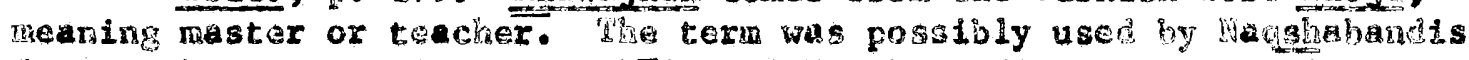
Guring the Ottoman Lmpire. Lhälid al-Haqshaband, as previously mentioned,

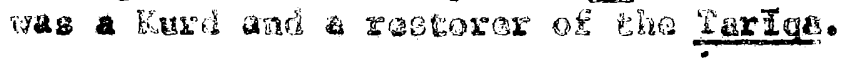
24 bist. 


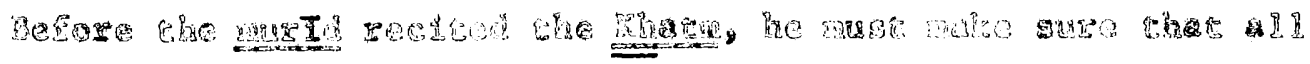

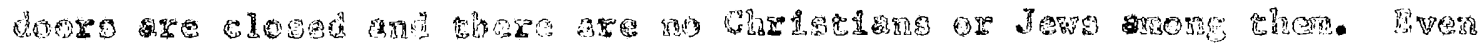
L

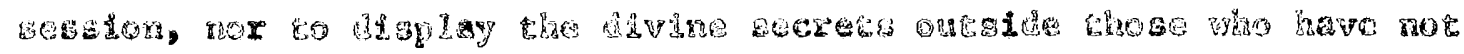

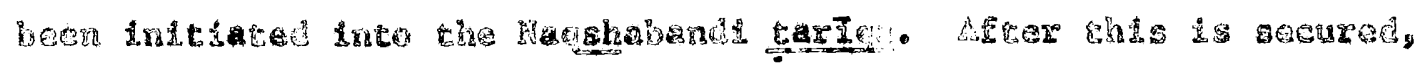

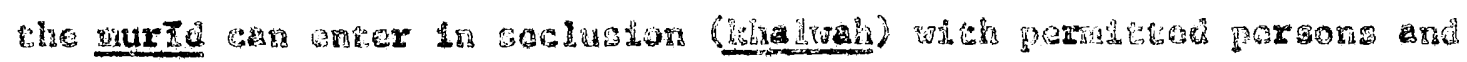

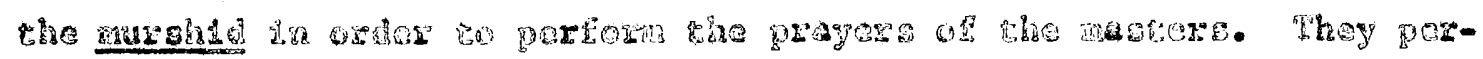

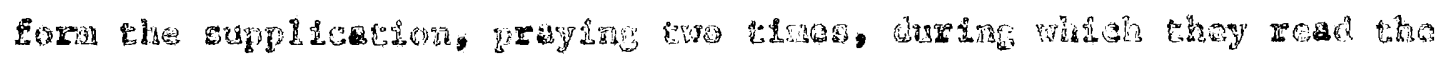

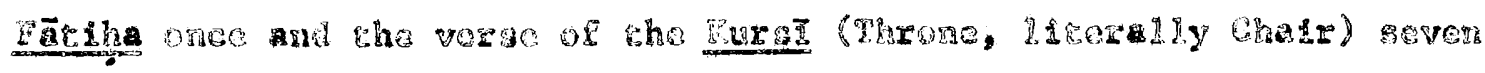

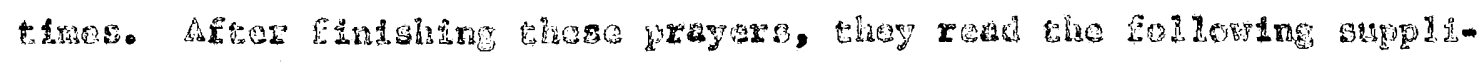
Caten ELent ly:

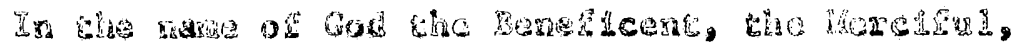

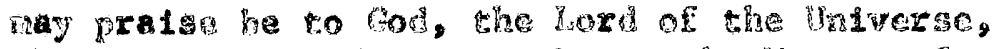

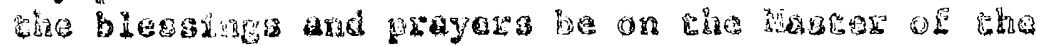

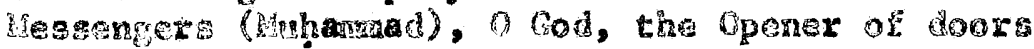

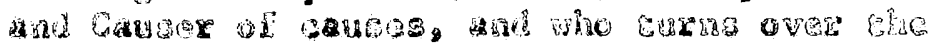
hearte and stghes, Gute of the perplerect, and

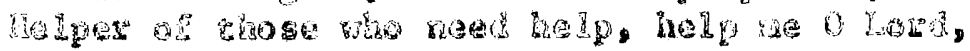

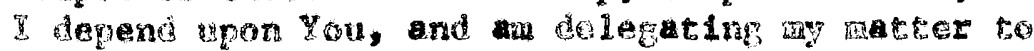

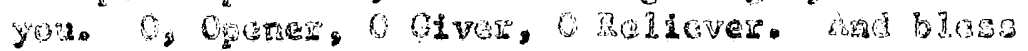

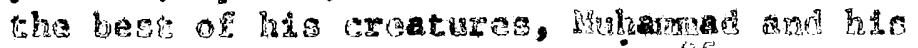

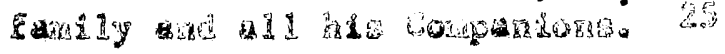

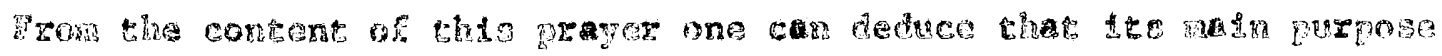

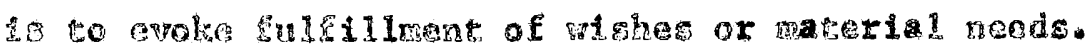

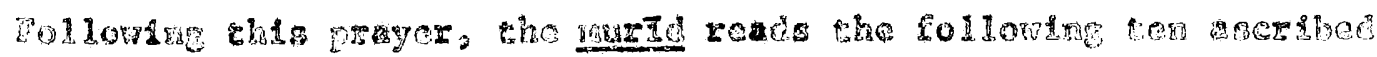

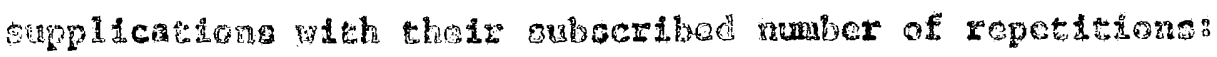

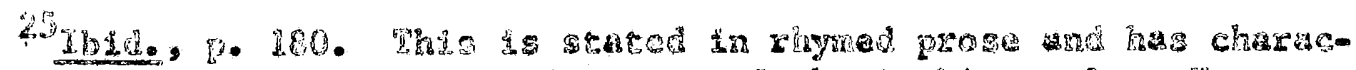

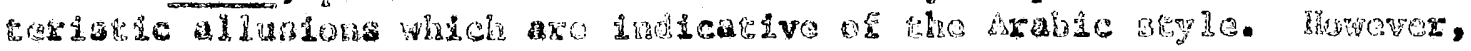

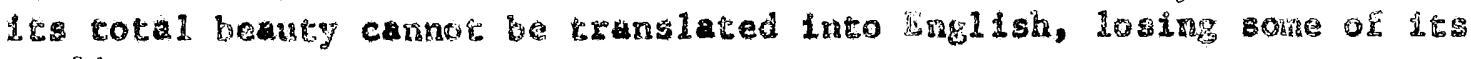
arealitey. 


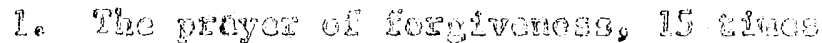

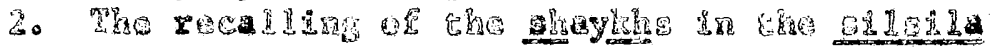

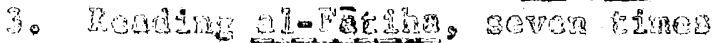

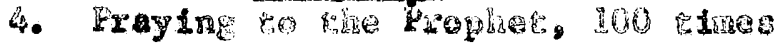

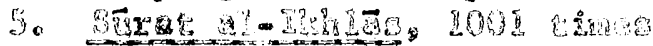

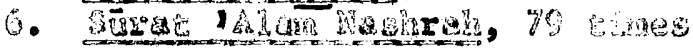

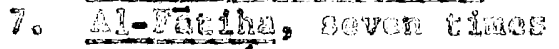

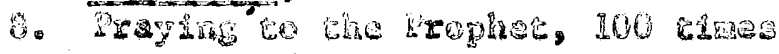

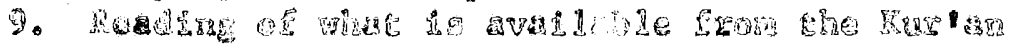

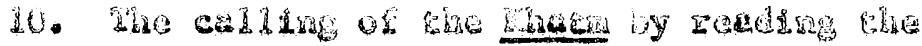
MUgOA

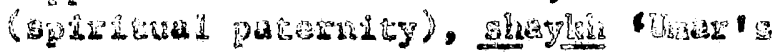
crymy 2.

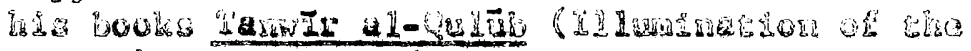

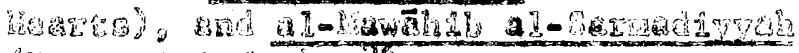

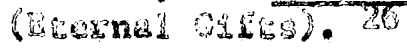

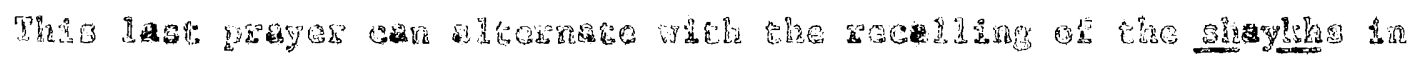
Hhe S18

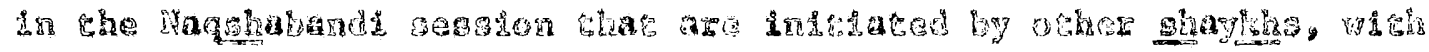

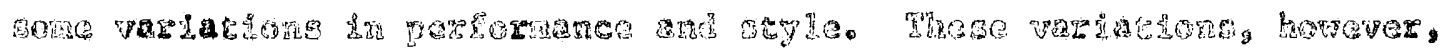

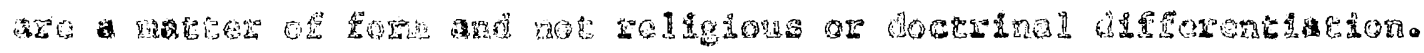

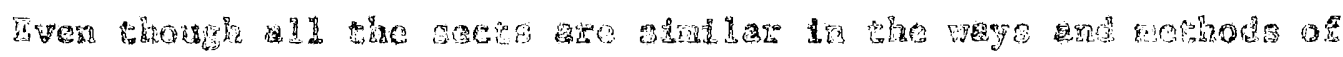

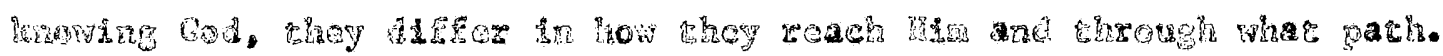

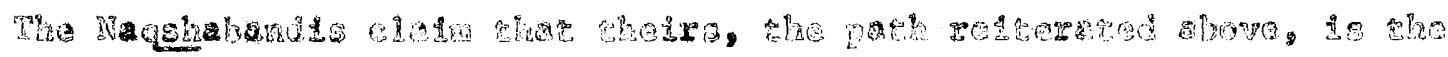

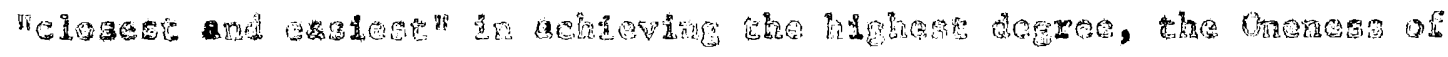
Ge.

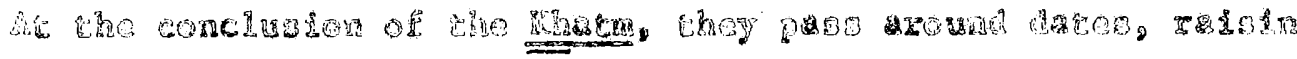

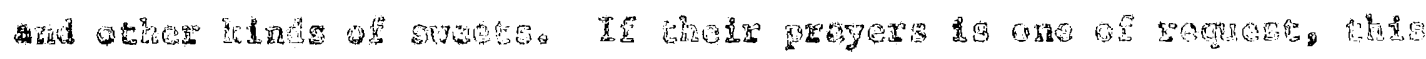
why

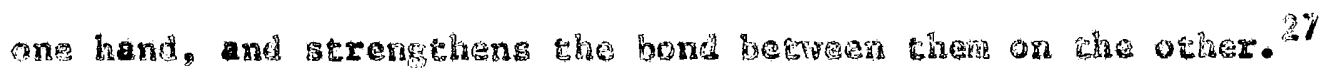

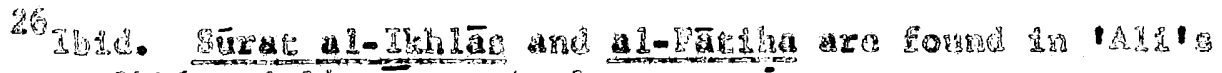
G日E

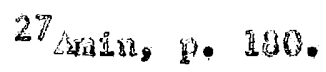




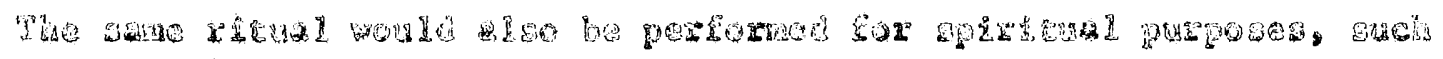

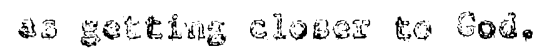

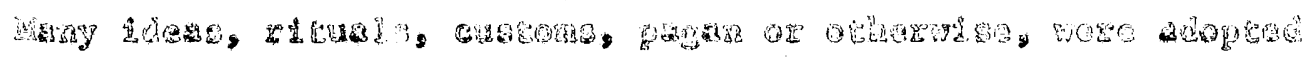

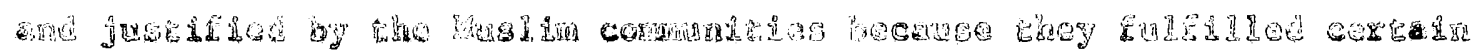

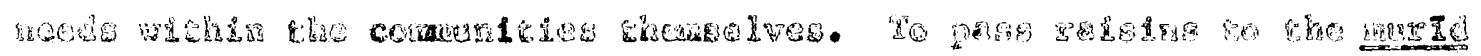

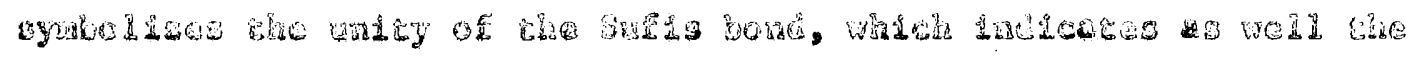

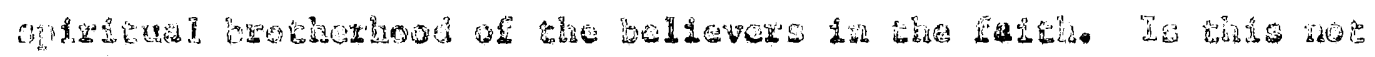

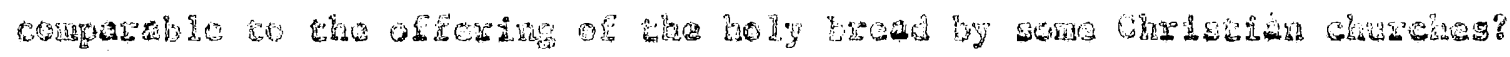

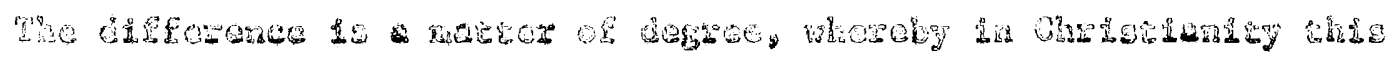

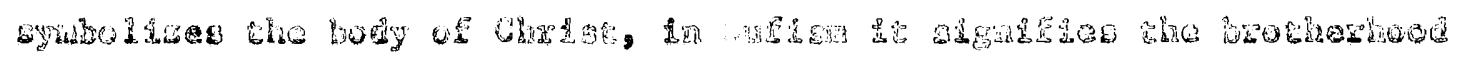
of ias 


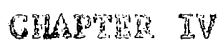

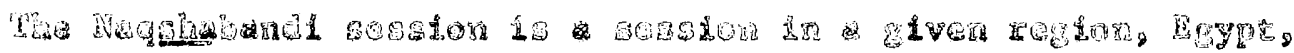

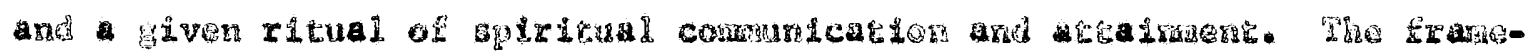

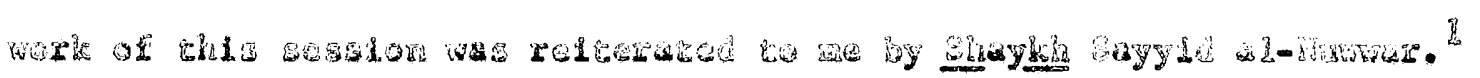

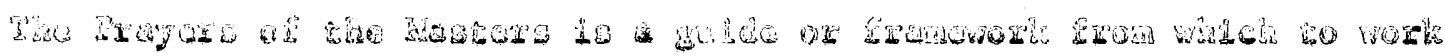
कH I

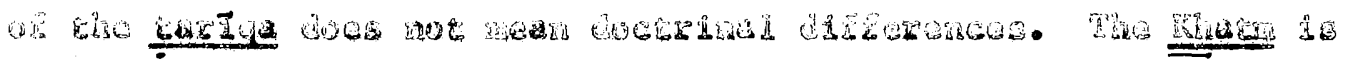

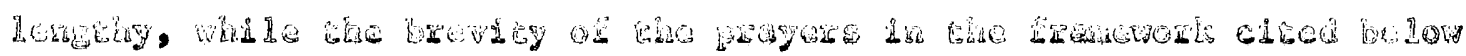

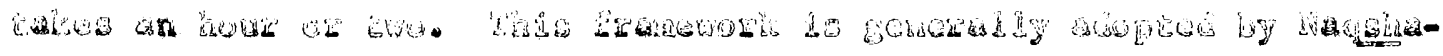

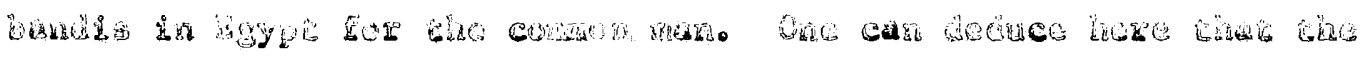

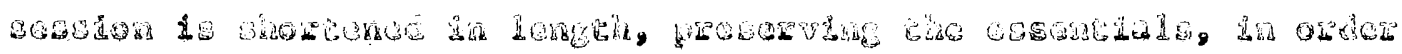

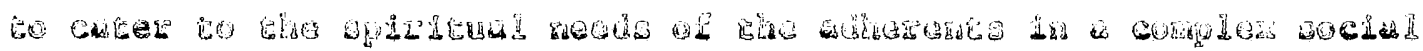

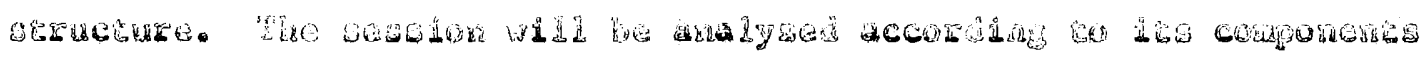

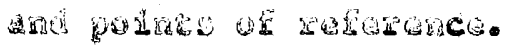

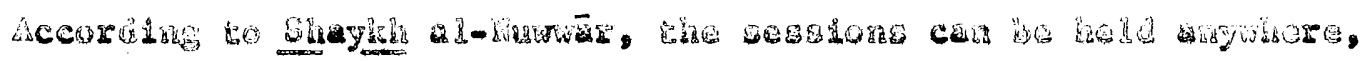

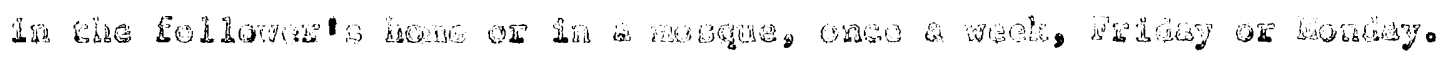

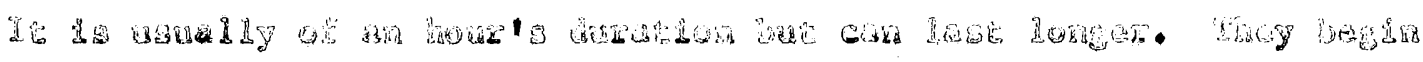

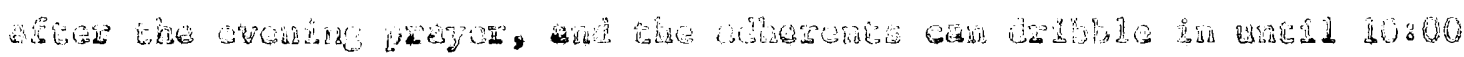

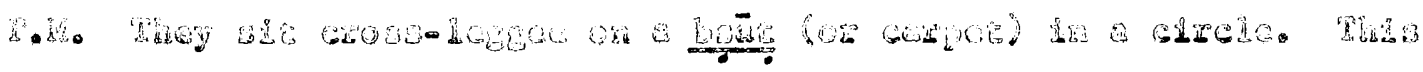

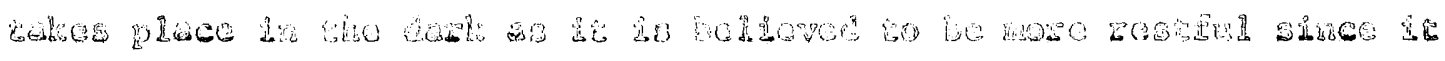

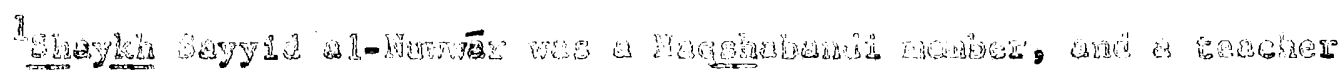

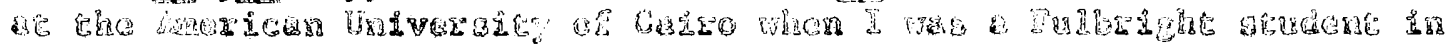
$196-620$ 
enduces calm and peace. The doors must be closed so as no prayer shall reach the earg of a non-member. They drink Turkish coffee or irfa (made of clnnamon sticks), chatting, unt1l eight or ten persons are present before they can commence. Women are not allowed to atcend but can hold their own sessions in different place but on the sarie nights.

filthough the Naqghabandis orlginally wore caps, generally white, of peculfar shapes, many made up of gores or sections, which varies in number in different dervish orders, there is no strict adherence to the attire today. The cap was always enbroidered and originally contained verse from the Kurlan.

\section{Set intual of Communication}

There is a prescribed ritual which ensues and is adhered to at every weting. Flrst, they comence their devotions with al-Fätien, or the Gpening, from the Rur'an. This has been called the Lord's rayer of the Nuslims and is, therefore, an essential part of their pubile as well as their private worship. The Opening is then followed by a nashId (song) from Kalän al-Näs (Word of the People). A silent dhikr follows which is repeated for about 15 rainutes and is said slowly; thut 1s, "Ihere is no God except Alleh," then simply "Mlah" so that the emotional efrect increeses. Is previously mentloned the dhikr is a shorter and simpler path by which a spiritual satisfaction can be achieved in comparison to attaining the hal (state) which is a laborious and arduous mystic IIfe not within the powers of every nember. The stages, however, which are in essence Path, Gnosis (mafrifa), and Truth, 


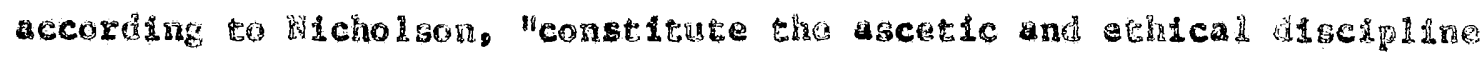
of the Bufi, and aust be carefrily ulatingi ishe frow the so-called

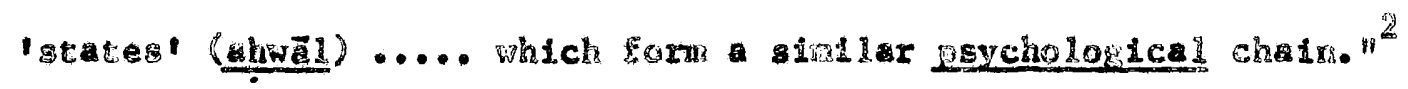

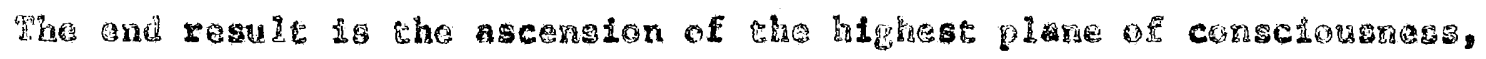

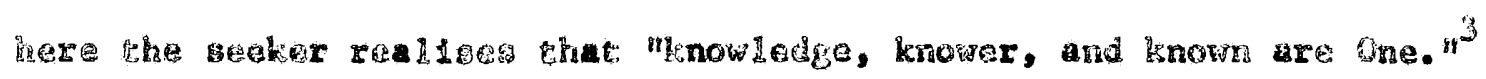
"rhere is no God," then, is ghrase of denial, the nothingness

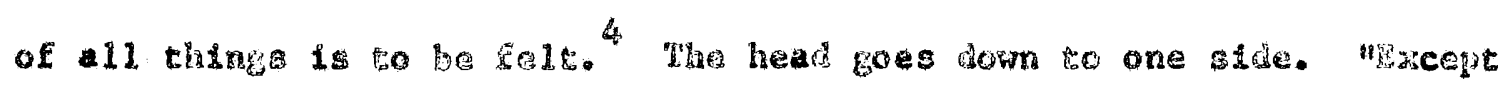

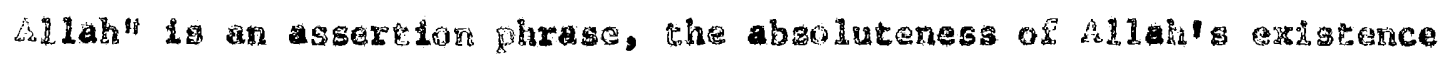
met be felc. "The head goes town to the other side. The breaching

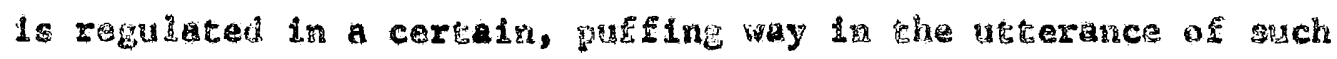
Eormulae as thege and the trord "Mlah" so that the emotional affect increases. At this point they produce in theraseives a gloasant areariness or a strange inture of asthetic pleasure, derived frow

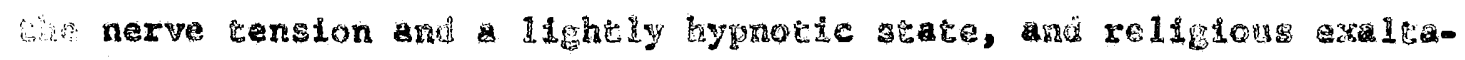
BLon.

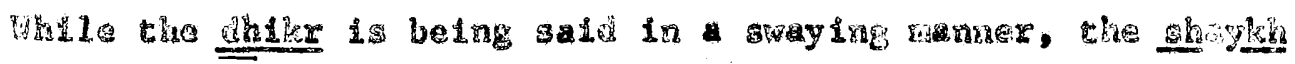

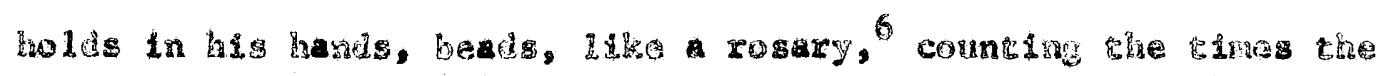
phrase wos repeated.....

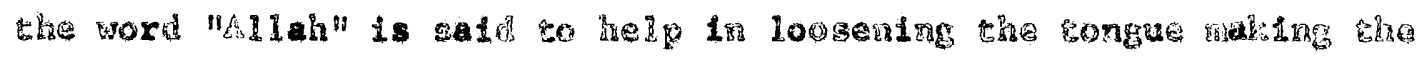

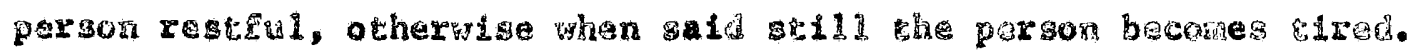

2Hicholson, isystics, p. 29 .

3 Ibld.

4iaclonalu, p. 162.

5 Ibld.

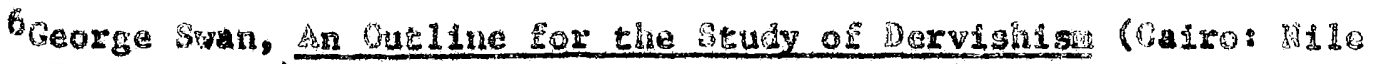
Fission Press, 1925). According to Swan, the use of the rosary was to induce "contemplation and ecsiasy" and is borrowed frow budahisa. 


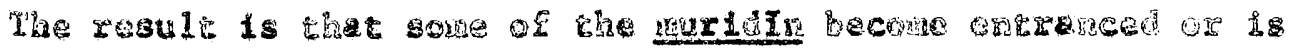

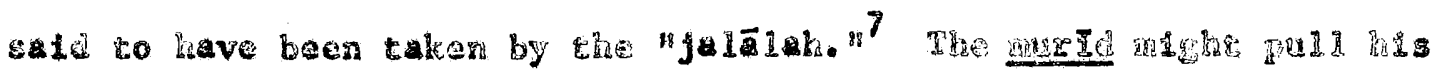

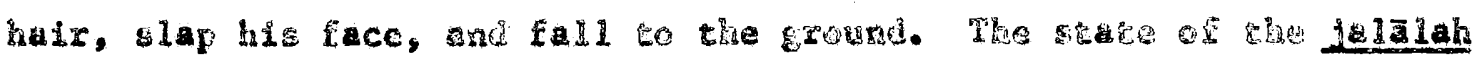

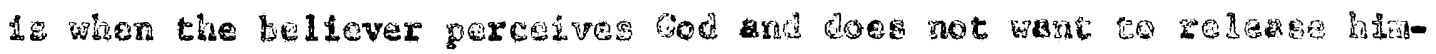

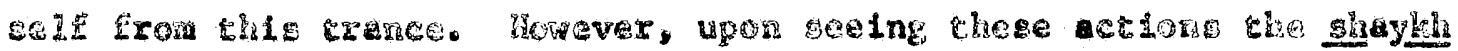

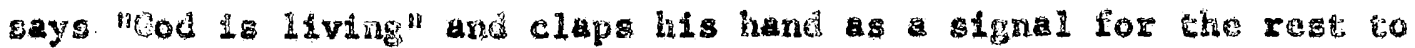

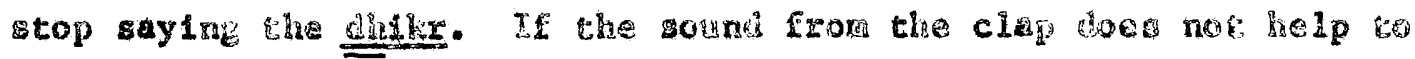

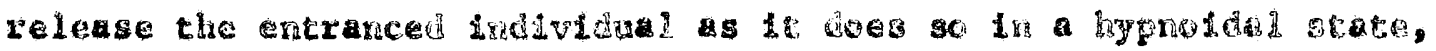

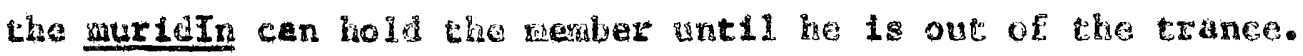

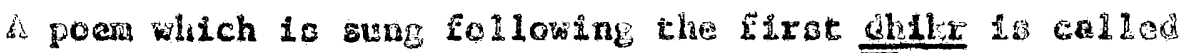
"teaklwarr, nis a proparation es a kind of a pactelar for the second dhikr. Surat al-Zkhlass (Furity) frot the kurian follows and is salu oilenty. It slgnifies the neture and qualities of God and it as follots:

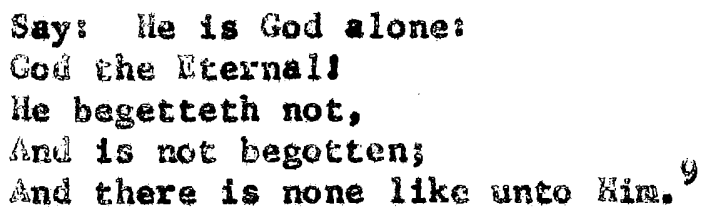

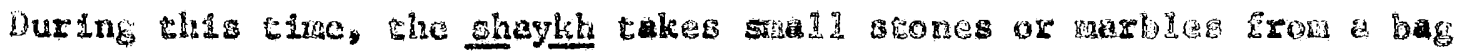

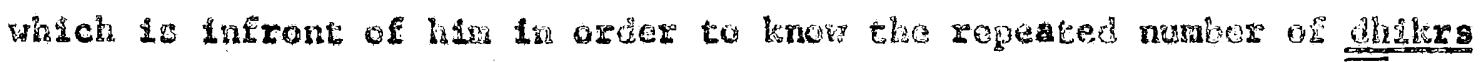
that las been sald and places te to one side. Ae traed a song followe If someone has a good volce. When the third dhikr is lollowed by

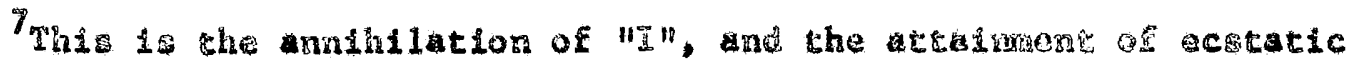
cormunion with God.

Bakhnir 11terally means fermentation. This is applied to the preparation of the individual for the next stage.

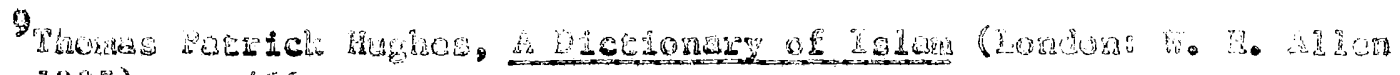

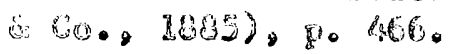




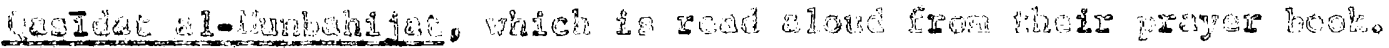

\section{GLsing Payer}

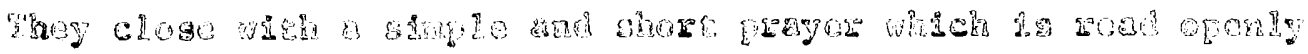

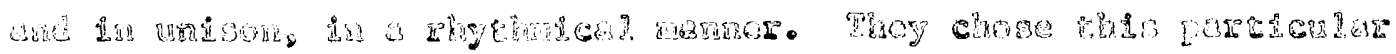

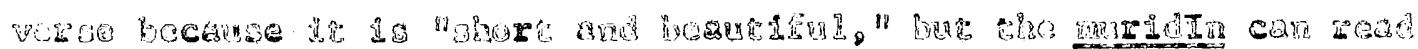

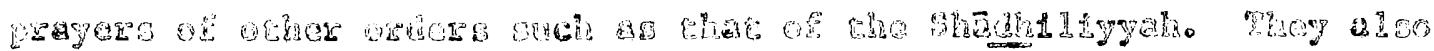

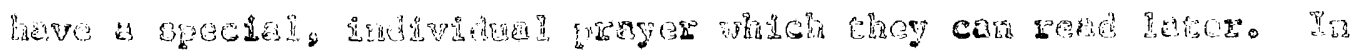

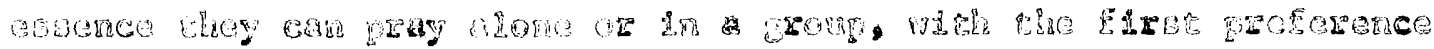

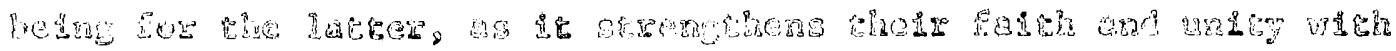

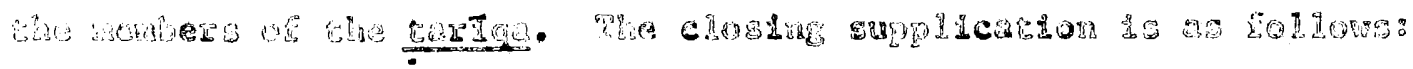

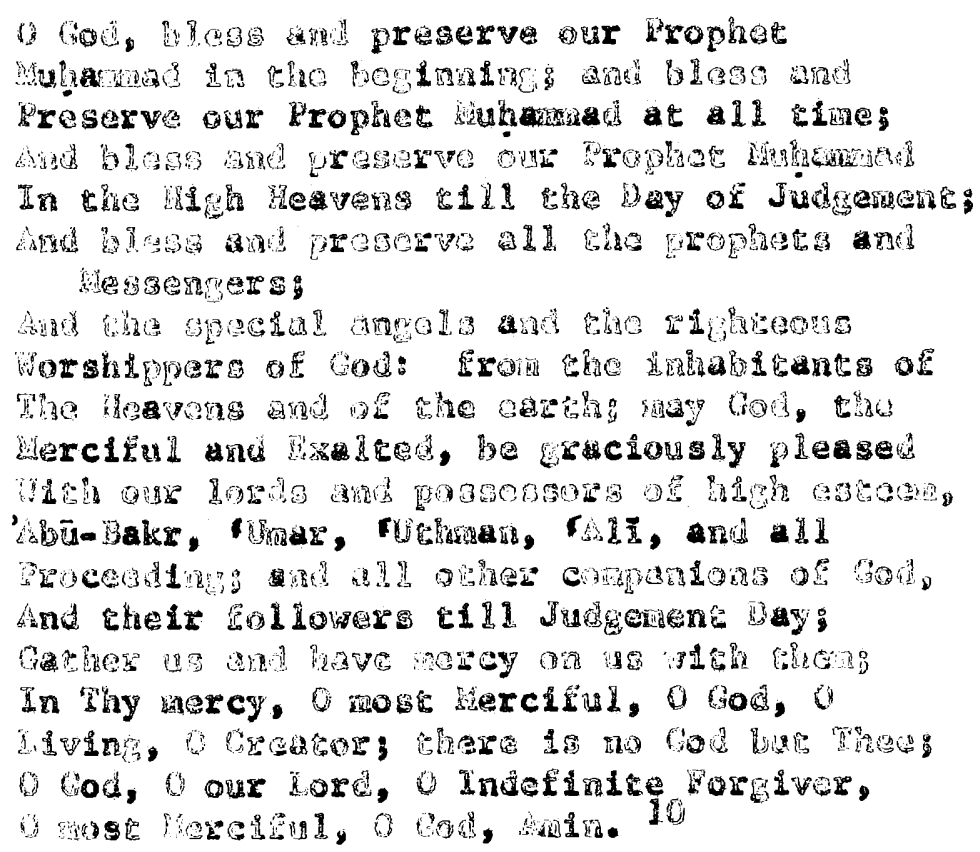

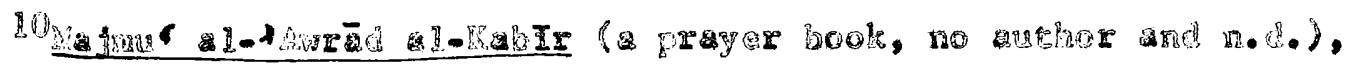
DE. $286-127$. 


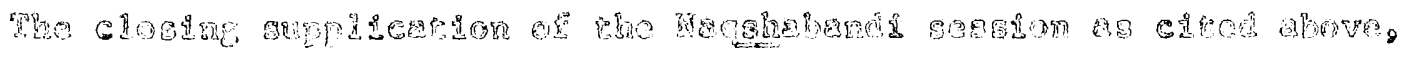

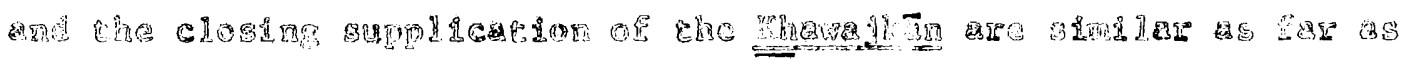

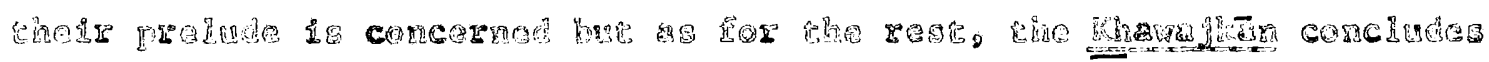

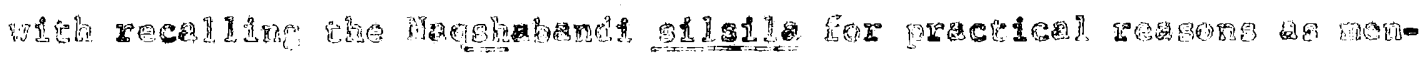

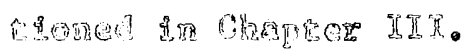

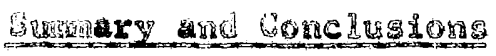

Tho mas

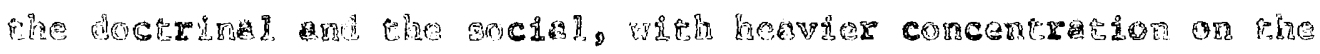

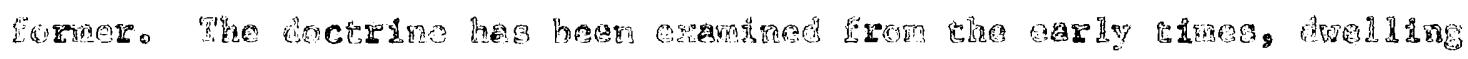

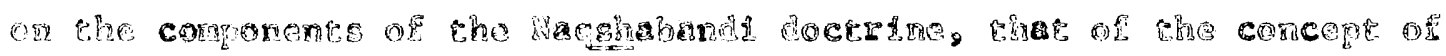

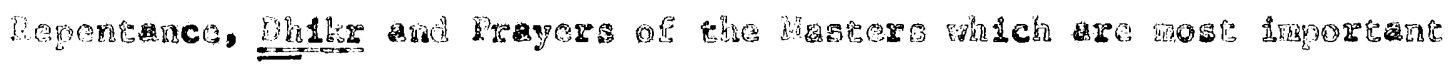

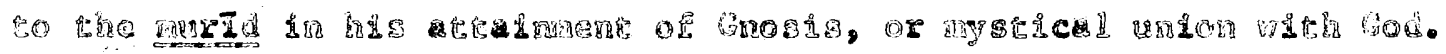

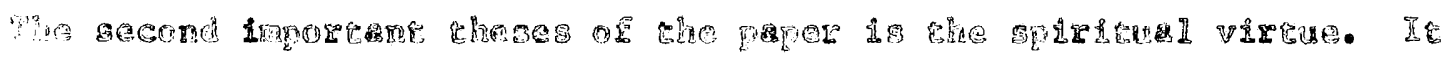

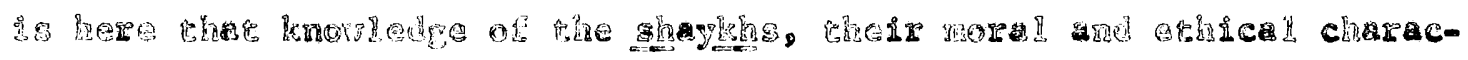

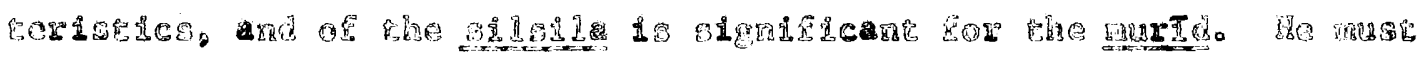

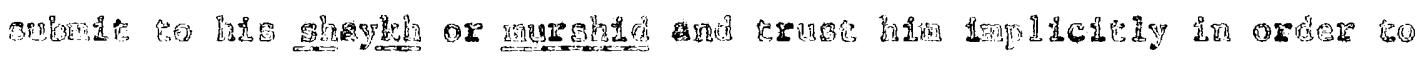

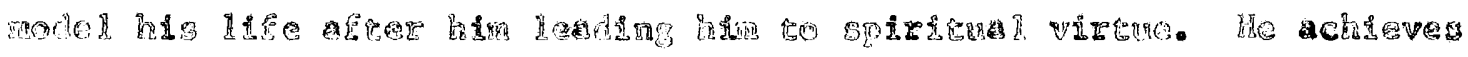

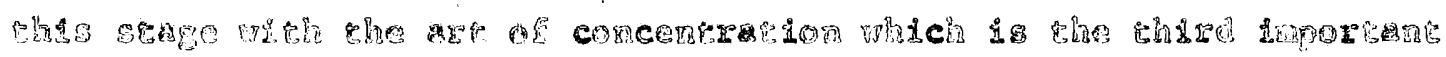

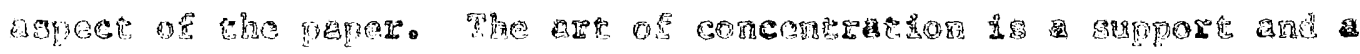

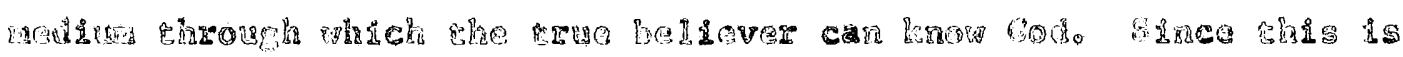
Joc

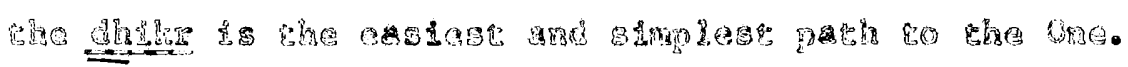

"7?

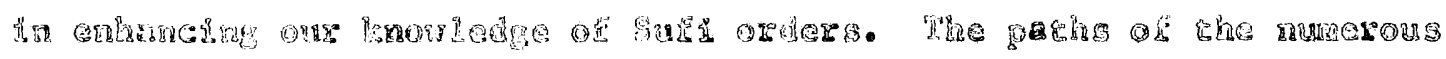

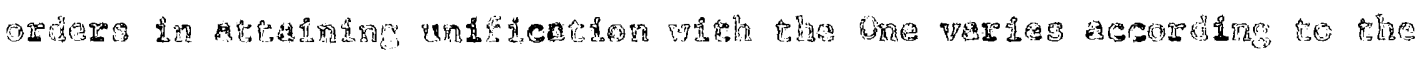




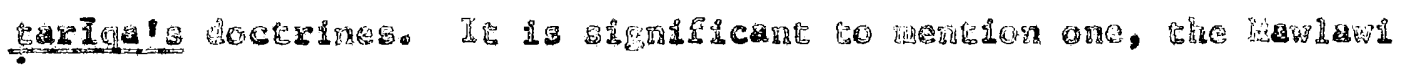
Quz

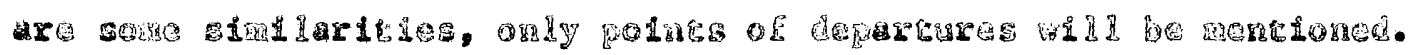

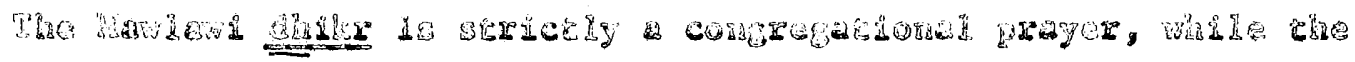

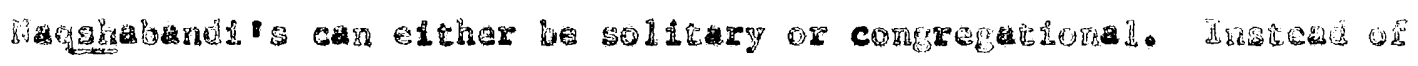

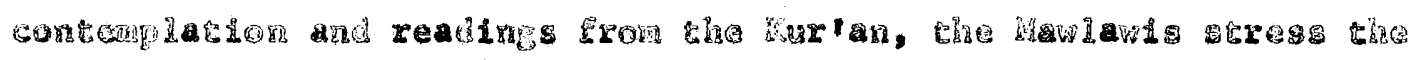

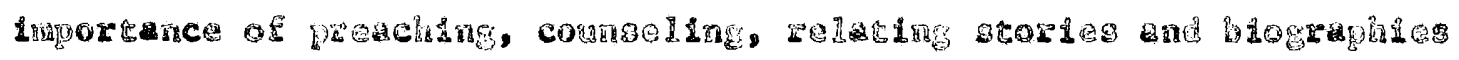

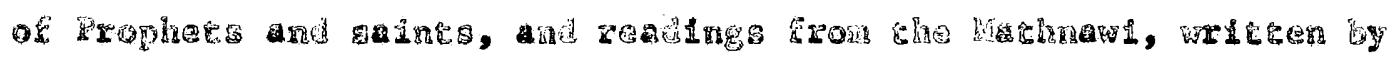

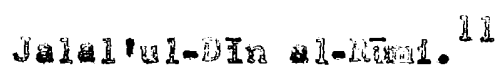

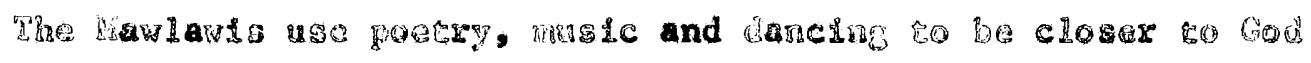

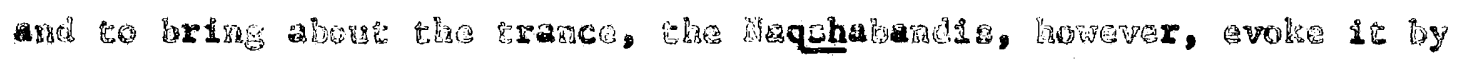

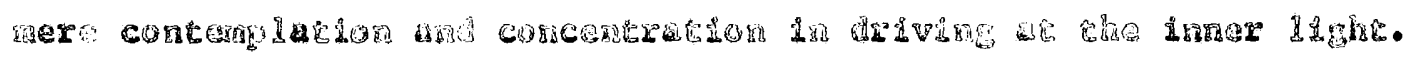

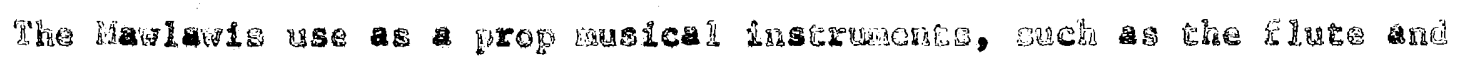

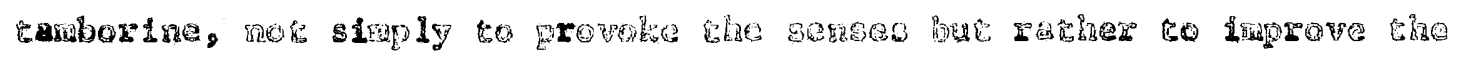

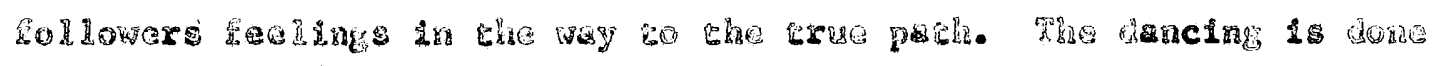
Lis

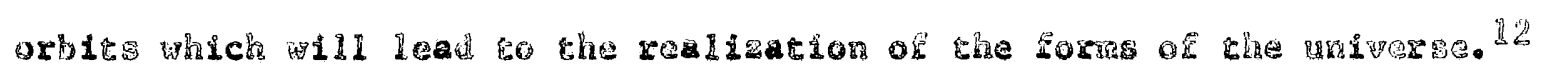

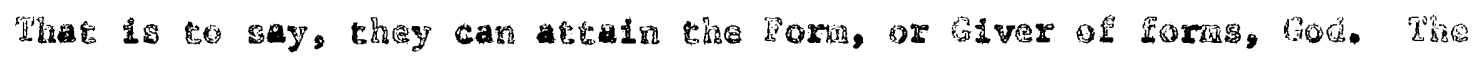

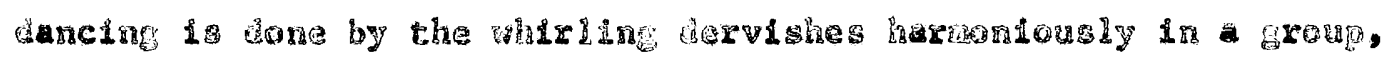

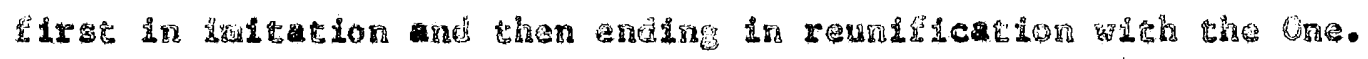

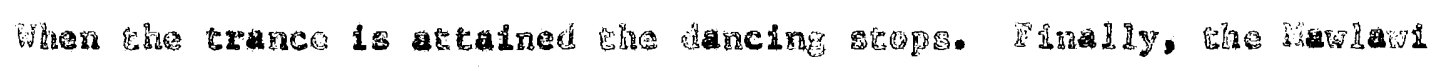

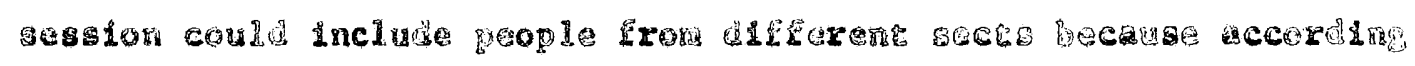

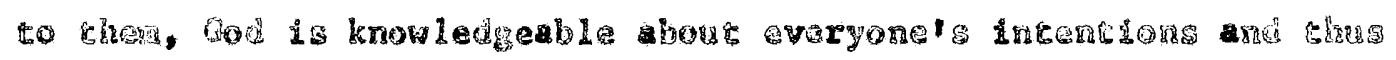

\section{1}

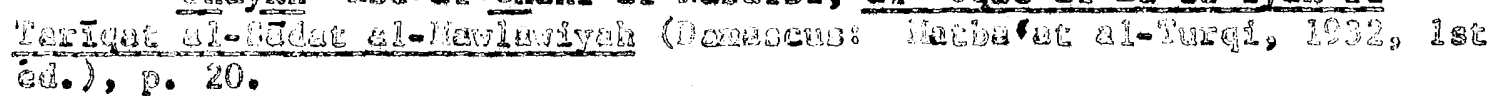
Lig 
there is no secrecy, contrary again to the Naqshabandi session.

A second inportant doctrinal observation is the concept of

Light. Thete are two interpretations, one exoteric, the other eso-

ceric. The suhrawdis interpret the "loctrine of Light" esoterically,

that God is Light, which is a budra (innovation) and is unacceptable

by orthodox Is lam. It is this interpretation which caused differences

among Naqshabandis in later times. The concept of light, anong other

Naqshabandi practices, was later condemed as a source of confusion

and innovation by Narghabandis. The highlights of these differences

were articulated by Shellabear in his translation of "An Exposure of

Counterielters" of a Malay treatise. The translated text explains

that those

who believe that Allah is a shining light

which has nothing like it are kefirs...

those tho believe that Allah is like that are

unbelievers, for they believe that Allah has

the quality of shining, and shining is an

orifinated quality, like the quality of fire and

the sun and evexything that shines. The

faithfuI has no doubt that those who have such

a belief as that axe unbelievers, for they

belleve that AJlah is Light. Their un-

belief is caused by their ignorince of the

qualities of Allah and the Science of his

Unity (TawhId). 13

13H. G. Shellabear, "An Exposure of Counterfelters," Moslea World, vol, 20, 1930, p. 361. (Shellabear discusses a lalay treatise which was wricten by 'thmad Khatio Ibn CAbdull-Latrif as an exposure of "false teachings and irregular practices of certain teachers of the Nagshaband1 Brotherhood in that part of Sunatra." He expounds on five questions, concluding that the order should urge the study of the sctences, Figh,

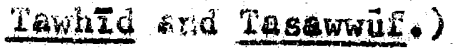


The doctrine of Light which is accepted by Naqghabndis is that of an exoteric interpretation, the light of cod. The reference to Light by a Nagqgabandi is used metaphorically; that is, God gives the gift of grace to the one who repents and lives according to the tariga. The Light of God is medium through which the souls of the believers are unified on one level and through the silsila which functions as a communicator between the hearts and the Light of God, which is grace, on the other. This one doctxinal controversy is brought out here only to make the reader aware that whatevex is generally accepted in a given tariqa does not necessitate absolute standards for adherence, only relative to tine and place.

In conclusion, Sufism as institution sprang and was nurtured, as in other religions, as result of general conditions and causes whthin the structures of the society. Sufisra not only was one of the factors that expressed the spirit of society in religious and soclal term, it vas a way of Iffe to Muslinn. According to Williams, it took the place of "church denominations, social club, Hasonic lodge, night school, burial association and marching society,"14

When men in society finds anxieties and conflicts in given path, there has to be alternate routes of departure, if not, then some conceptualization of thoughts and ideas must stem to fill the vacuun for him. If there are too many external obstacles, then an internal reign takes hold to give meaning and order to man's existence and self

\footnotetext{
${ }^{14}$ John Alden Will 2ars, Islan (New York: George Brazi11er, 1962), p. 169.
} 
suld 11ment. If man cannot find spiritual and intellectual answers inwardly, he must find order and reaning in the external world. The balances must be net in wan and he nust find his self and inner scrength, both spiritually and socially. In other words, the relatonshtps between man and and than and Goù must be clarified and realized. The range for its attaiment is wide; be it on one pole the use of narcotics such as LSD and alcohol, or on the other, concentration and contemplation as with a Naqshabandi Sufi. 


\section{BIBLIOGRAPH}

BOOKS

Books In Arabic

Abu-Rayan, Hohamed. Hayäkil al-Nür: Suhrawar 1 al-Ishräq1. Egypt: a1-Haktabat al-Tijariyah a1-Kubrah. lst ed., 1932.

Abu-Zahrah, Muhanmad. Tarikh al-Madhahib al-Islamiyyah. Dar a1-Fikr 1-Arabi. 2 vols. $\left(n_{0} d_{*}\right)$

CAEffi, Abü al-rAla', al-Tassawwü, al-Thawrah al-Ruhiyah fi al-Isläm. Egypt: Dar A1-Marärif. 1963.

- Introduction to Fusüs al-Hikm: Ibn al-CArabi. Ëgypt. 1946.

Amin, Shaykh Muhammad. Khaläsat Kitäb e1-Mawähtb a1-Sarmadiyyah.

1374 H: (no place of publicatlon.)

a1-Asbahän, Alunad B. CAbda1lah. Hilliyyat al-lAwliyal. Egypt: Published by al-Khanji and al-Saradat. Vol. I. 1st ed. 1351. H.

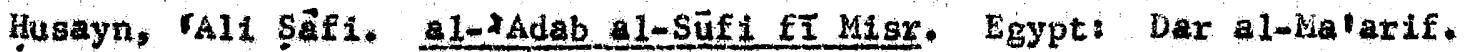
1964 .

Jän1 21-1Usă. Egypt. 1st ed. $1328 \mathrm{H}$.

21-Karkaly, Khayr-a1-DIn, al-A läm. Egypt, 3 vols, 1927.

Majmu al-Awizd al-KabTr. (a prayer book.) n.d.

Massignon, Louls \& Raul Kraus. Akhbär al-Halläj. Arabic-French text. France: Imprimerie "Au Calame." 1936.

1-Nabülsi, Shaykh cAbd-al-Ghäni. al-CUquad al-Ludlullyah fI TarIg a1-Sădat a1-Nawlawiyah. Darascus: Natbalat al-Turqi. Ist ed. 1932.

1-Tasawwüf al-Is1āmi. Presented by Mashzkhat IUmum 21-Turuq al-Sufiyyat. Ceiro. 1958. 
Books in English

A11, ther. The Spirit of Islam. London: Christophers. 1935.

Arnold, S1r Thonas \& Alfred Guillaume. The Iegacy of Islam. London: Oxtiord University Press. 1960.

a1-Baghdad1, Abu-Hansur Abd-a1-Kahir Ibn Tahir. Moslon Schisms and Sects (al-Fark Bain a1-Firak). Translated by Ebroham $\mathrm{S}$. Halkin. Palestine. Part II. 1935.

Brown, John P. The Dervishes. London: Trubner \& Co. 1860.

Burckhardt, Titus, An Introduction to Sufi Doctrine. Translated by D. M. Matheson. Pakistan: Ashraf Press. 1959.

The Encyclopedia of Islam. Vol. III. London. 1936.

Gibb, Sir Namilton. Mohammedanism. London: Oxford University Press. 1957.

- and Harold Botten. Islanic Society and The West. London: Oxford University Press. Vo1. I. 1951.

Hitti, Philip K. History of the Arabs. London: Macmillan te Co, Ltd. 8th ed. 1964.

Tughes; Thoms Patxick. A DLctionary of Islan. London: V. H. Allen \& $\mathrm{Co} .1885$.

Khan, Hazrat Inayet, The Sufi Message of Hazrat Inayat Khon. Published for International Headquarters of the Sufl Movement, Geneva. London: Darkie \& hock1iff, 8 vols. 1960.

Lewis, Dernard. The Arabs in Hstory. New York \& Evanston: Harper \& Row, Publithers, 1960.

Mahnud, Sayy 1d Fayyaz, A Short History of Islar. Pakistan Branch: Oxford University Press. 1960.

Nast, Seyzed Hossein. Ihree Muslin Sases. Cambridge: llarvard University Press. 1964.

Ncholson, Reyno 14 A. The lfystics of Islan. London: G. Bell E Sons LEds. 1914.

- A Literary Hstory of the Axabs. Cambridge: The University Press. 1953.

Dayne, Robert. The Holy Sword. New York: Collier Books. 1962. 
Picktha11, Hohamed Marmaduke. The Glozious Koran. A Mentor Book. Fublished by the New Amertean Library. 1954.

Safran, Nadav. Euypt in Search of Political Cormunity. Cambridge: harvard Universtty Press. 1961.

Seelye, Kate Chambers. Moslen Sohisins and Sects. Nev York. 1920.

Swan, Geoxge. An Outline for the Btudy of Dervighism. Gairo: Nile Mission Press. 1925.

Underhi11, Evelyn. Hysticism. London: Siethuen \& Co, Ltd. 1949.

Watkin, I. I. The ghilosophy of Hysticlsin. Net Yozk: Harcourt, Brace हf kowe. 1920.

Willans, John Alden. Islan. New York: George Braz111er. 1962.

Ziadeh, Nicola A. Sanusiya. Lejden: E. J. Bxill. 1958.

Books in French

Nader, Abert N. Les Principales Sectes Musuimanss. Inprimerie Catholique. Batrut. 1258.

Schaya, Leo, La Doctrine Soufique de LUnite. Librairie DVAmerique et Dorient, Adrien-Ma Isonneuve, Paris. 1962.

DeVau, haron Carra. Les Penseurs de Llslan. Daris: Librairie

Paul Geuthner. 1923. 


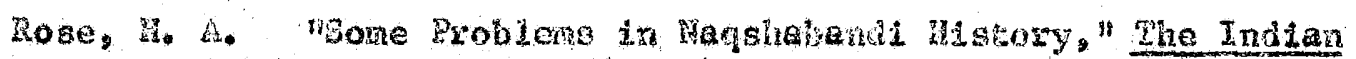
Sntiquary, vol. $52(1923), 204-211$.

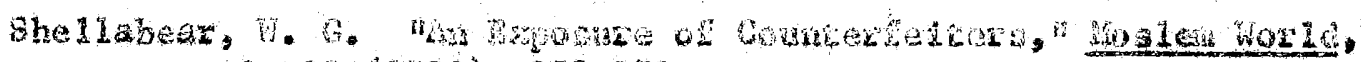
vo1. $20(1930), 359-370$.

ZALPS

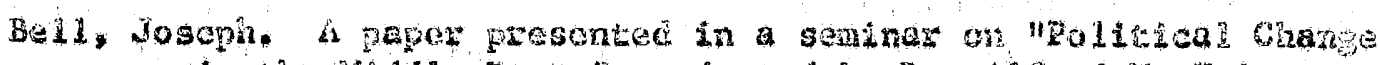

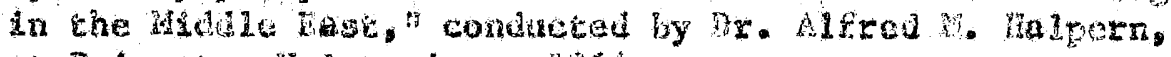
as Pranceton Unaperalty. $196 \%$.

\section{INTSERTM}

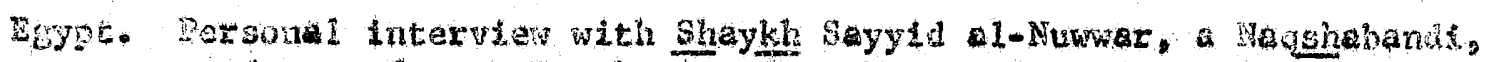
and a profesar ot the Arerican Undversity of Cairo. 
APRENDTX 
An interesting observation that $I$ found in researching the silsila was discrepancy regarding the biographical data of the Naqghabuni order as to its exact origin. The Encyclonedia of Islam indicated that Huhanrad Bahal a1-Din al-Bukhärj is the founder of the order and that it was propagated from India. This was the general consensus among Oriental scholars including the eninent H. A.R. Gibb who stated that the order, fomded in the fourceenth century in central Asia, also gained irpetus in Inaia. 1

Inayat Khan, an Indian mystic, indicated that the roots of Sutism reached back to a Sufi school which existed in Egypt; however, he ald not indicate the particular school. From this school, he further asserted, four others developed, one of which was the Naqshabandi order; from these schools, branches sycang forth in drabta, Palestine, Turkey, Tartary, Bokhara, Afghanistan, Inda, Siberia, and othex parts of Asia. ${ }^{2}$ On the other hand, Brown asserted thet after the Prophet's leath 45 citizens in Hecca took oaths of "ffidelity to the doctrines of their Prophet and formed a sect or fraternity..... ${ }^{3}$ He further asserted that the first known order was the "olwanees" founded by Shaykh Olwan, A. D. 766, at Jedda which was later perfected by the Qädiris. 4

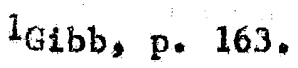

2Khan, vol. 11i, p. 18.

3 Brown, p. 207.

${ }^{4}$ Ibdd, p. 209.
} 
Fur themore, Reynold Hicholson belleved that Ma fruf al-Karkht, an Ireags, who died in 815 A.D., founded the oldest known sufi definition. 5 According to the second sistla of the Naqshabarid order, Harute al-karlihi was the shaykh of the first chain and the two chains united with hira. The death of SAbi CAII al-Farradi, who is mentioned in the first chain as being the shaykh of the third silsila, is $470 / 1078$ As. H. Aose indicates. Rose also includes a biographlcal. sketch of

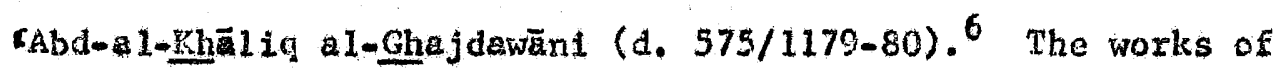
1-Ghajdawani who recited the dhikr silently ..... see Chapter II ..... later became the basis of the Naqshmband1 dhikx. While al-Bukhäri, who is considered the founder, collected the sayings of al-Ghajdawani. Furthermore, as stated earlier the Naghabandi order is indebted in its strength and diffusion to l-Ghajdawāni"s leadership.

The point to be made here is that the silsila is no longer a spirtual connection without historical proof. If the above assertions are valid, and there is no evidence to the contrary, l-Ghajdawani or sone other shaykh mentioned in the stlshla founded the Naqshabandi order prior to the fourteenth century. In either case the order was established prior to the general consensus of opintion among Orientalists. As to Khan's assertion that the Naquhaband1 ordex began in Egypt, there is no suffictent proof to substantiate this claim. Since the first

Sicholson, Literary, p. 385.

6H. A. Rose, "Some Rroblems in Naqshabandi History," The Indian Antiquary, vo1. 52,1923, p. 204. 
order began in Jedde, it is posslble that the Naqshabandi order was: Elrst estahlished 1n Egypt, propagated in Kurdistan where popular venexation of shoylehs and other unorthodox practlces were connon in the fourteenth century, revitalized in the efghteenth century under Sleykh Khalld, further gained impetus in later centuries in India. At the same time its mystical concepts were being perfected here. Stnce the Naghebandi order flourished in Syria in the ningtenth century, tt could have been reintroduced or revitalized in Egypt in the 1900 's. The reason for this reintroduction stems from the fact that oftentimes the orders and sects go astray when the shaykh, who is virtually the absolute master of a given area, dies. 